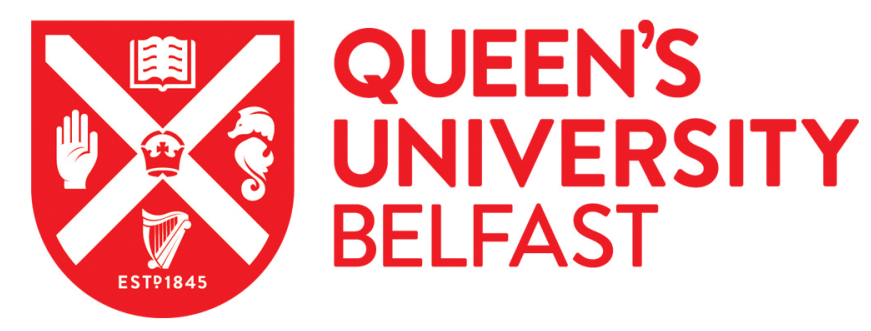

\title{
Effects of Elodea nuttallii on temperate freshwater plants, microalgae and invertebrates: small differences between invaded and uninvaded
} areas

Kelly, R., Harrod, C., Maggs, C. A., \& Reid, N. (2015). Effects of Elodea nuttallii on temperate freshwater plants, microalgae and invertebrates: small differences between invaded and uninvaded areas. Biological Invasions, 17(7), 2123-2138. https://doi.org/10.1007/s10530-015-0865-8

Published in:

Biological Invasions

Document Version:

Peer reviewed version

Queen's University Belfast - Research Portal:

Link to publication record in Queen's University Belfast Research Portal

\section{Publisher rights}

Copyright Springer International Publishing Switzerland 2015.

The final publication is available at Springer via http://dx.doi.org/10.1007/s10530-015-0865-8

\section{General rights}

Copyright for the publications made accessible via the Queen's University Belfast Research Portal is retained by the author(s) and / or other copyright owners and it is a condition of accessing these publications that users recognise and abide by the legal requirements associated with these rights.

\section{Take down policy}

The Research Portal is Queen's institutional repository that provides access to Queen's research output. Every effort has been made to ensure that content in the Research Portal does not infringe any person's rights, or applicable UK laws. If you discover content in the

Research Portal that you believe breaches copyright or violates any law, please contact openaccess@qub.ac.uk. 
1 Effects of Elodea nuttallii on temperate freshwater plants, microalgae and

2 invertebrates: small differences between invaded and uninvaded areas

3 Ruth Kelly ${ }^{1 *}$, Chris Harrod ${ }^{2,3}$, Christine A. Maggs ${ }^{2} \&$ Neil Reid ${ }^{1,2,4}$

$4 \quad{ }^{1}$ Quercus, School of Biological Sciences, Queen's University Belfast, Belfast BT9 7BL, UK

$5 \quad{ }^{2}$ School of Biological Sciences, Queen's University Belfast, Belfast, BT9 7BL, UK

$6 \quad{ }^{3}$ Instituto de Ciencias Naturales Alexander Von Humboldt, Universidad de Antofagasta, Avenida Angamos

7 601, Antofagasta, Chile

$8{ }^{4}$ Institute of Global Food Security (IGFS), Queen's University Belfast, Belfast, BT9 5BN, UK 9

10

11 *Corresponding author: Tel.: +44 289097 2464, +44 77 07627488, Fax: +44 289097

12 5877; E-mail address: ruth.kelly@qub.ac.uk

13

14 Key words: $\quad$ Algae, aquatic, invasion, limnology, macroinvertebrate, macrophyte

15 Running title: Impacts of Elodea nuttallii 


\section{Abstract}

18 The invasive aquatic plant species Elodea nuttallii could pose a considerable risk to European

19 freshwater ecosystems based on its current distribution, rate of spread and potential for high

20 biomass. However, little research has been conducted on the impacts of this species on native

21 biota. This study takes an ecosystem-wide approach and examines the impact of $E$. nuttallii

22 on selected physicochemical parameters (dissolved oxygen and $\mathrm{pH}$ ), algae, invertebrate and

23 macrophyte communities. Elodea nuttallii had small but significant impacts on plant, 24 invertebrate and algal species. The richness of algal periphyton was lower on E. nuttallii than on native macrophytes. The taxonomic composition of invertebrate communities associated with E. nuttallii differed from that associated with similar native plant species, but did not differ in terms of total biomass or species richness. Macrophyte species richness and total cover were positively correlated with percentage cover of E. nuttallii. Not all macrophyte species responded in the same way to E. nuttallii invasion; cover of the low-growing species Elodea canadensis and charophytes was negatively correlated with E. nuttallii cover, whilst floating-rooted plants were positively correlated with E. nuttallii cover. All observed differences in the macrophyte community were small relative to other factors such as nutrient levels, inter-annual variation and differences between sites. Despite this, the observed negative association between $E$. nuttallii and charophytes is a key concern due to the rarity and endangered status of many charophyte species. 
38 Freshwater systems have been shown to be at particularly high risk from biological invasions

39 (Sala et al. 2000) and invasive aquatic plants are widely considered to be a major threat to both species diversity and ecosystem functioning (Strayer 2010). The assessment of potential impacts of invasive species on ecosystems is essential to the prioritisation of resources (Leung et al. 2012), and traits associated with successful naturalisation cannot be reliably used to infer potential impact (Hulme 2012). Despite this, in Europe there is a lack of studies directly assessing the impacts of aquatic species on natural ecosystems across trophic levels (Caffrey et al. 2014).

Invasive macrophytes can be 'ecosystem engineers', fundamentally altering ecosystems through alterations to habitat structure and water chemistry (Strayer et al. 2010). The impacts of invasive macrophytes on native macrophytes are more frequently studied than their impacts on algae or invertebrates (Evangelista et al. 2014). Invasive macrophytes are frequently observed to be dominant in plant assemblages. They may reduce overall macrophyte richness (Carniatto et al. 2013; Michelan et al. 2010; Stiers et al. 2011) and native seed banks (de Winton \& Clayton, 1996), and alter plant community composition (Mjelde et al. 2012; O'Hare et al. 2012). However, invasive macrophytes may benefit native plant species by altering the physical environment (e.g. stabilisation of sediment, reduction of turbidity or altering water clarity; (Rybicki, Landwehr 2007; Thomaz et al. 2012). Previous laboratory experiments conducted with Elodea nuttallii have shown that it can out-compete other submerged species (Barrat-Segretain 2005) and floating species when nutrient concentrations are not limiting (Szabo et al. 2010). However, floating species are likely to out-compete E. nuttallii in high nutrient conditions due to their superior ability to compete for light (Netten et al. 2010; Szabo et al. 2010). 
Algal periphyton is a key link between macrophytes and aquatic invertebrate species (Hamilton et al. 1992). Algal periphyton communities differ between plant hosts (Toporoska et al. 2008) both as a result of plant architecture (Declerck et al. 2007; Warfe, Barmuta 2006) and chemical exudates (Erhard and Gross 2006). Suppression of algal taxa by macrophyte exudates has been observed for several submersed species, including E. nuttallii and its congener Elodea canadensis (van Donk 2002; Wu et al. 2009). As competition with periphyton and phytoplankton is a major limiting factor for aquatic macrophytes, such allelopathy could constitute a substantial competitive advantage for these species. Allelopathic exudates may also affect zooplankton and macroinvertebrates, e.g. negative effects of Elodea spp. on growth and development of Daphnia spp. (Burks et al. 2000) and lepidopteran larvae in the family Pyralidae (Erhard et al. 2007). Many macrophyte species contain chemicals that deter grazing, and invertebrates and fish may preferentially select native macrophyte species as food (Burks, Lodge 2002; Schultz, Dibble 2012). Furthermore, the physical structure of different macrophytes provides different quality of refuges from predation (Kovalenko, Dibble 2014; Valinoti et al. 2011). In some cases, the increase in plant biomass associated with invasive macrophytes may increase the overall productivity of the invaded system, resulting in an increase in biomass and diversity of invertebrate species and changes in invertebrate community composition (Schultz, Dibble 2012). Elodea nuttallii is a submerged freshwater plant species which occurs in lakes and slow moving rivers, and which could pose a significant risk to European waterbodies based on its rapid spread and high abundance (Champion et al. 2010) and the observed impacts of $E$. canadensis. Whilst spread rates and suitability of European waterbodies for the establishment of E. nuttallii have been studied (Hussner 2012; Kelly et al. 2014a; Kelly et al. 2014b), little research has been conducted on the impacts of this species in invaded waterbodies. 
E. nuttallii was first introduced to Europe in 1939 and has spread rapidly, replacing the ecologically similar E. canadensis in many locations (Thiébaut et al. 2008). E. canadensis is considered to be one of the ' 100 worst' invasive species in Europe (DAISIE, 2015) and has impacts on macrophyte communities and aquatic food webs (e.g. deWinton, Clayton 1996; Kelly, Hawes 2005; Kornijow et al. 2005). E. nuttallii and E. canadensis are so similar that they may be ecologically and functionally redundant (Hérault et al. 2008), in which case their distribution and impacts could be expected to be similar. Both E. canadensis and E. nuttallii have high photosynthetic rates, show strong effects on $\mathrm{pH}$, dissolved oxygen and $\mathrm{CO}_{2}$ levels within plant stands (James et al. 1999) and may play an important role in phosphorus cycling in eutrophic systems (Angelstein, Schubert 2008). Field evidence suggests that E. nuttallii is replacing E. canadensis (Barrat-Segretain et al. 2001; BarratSegretain, 2002) and laboratory experiments have shown that E. nuttallii is more competitive than E. candensis (Barrat-Segretain 2005). Hence, the impacts of E. nuttallii could be more severe than those of E. canadensis.

According to the "invasion meltdown” hypothesis (Simberloff 2006) invasive species may facilitate the establishment or growth of other invasive species leading to accelerating rates of invasion; however, there are few empirical examples (Montgomery et al. 2012). Recent research on invasive macrophytes found evidence of facilitation of Egeria densa by Ludwigia grandiflora, but mutual inhibition between Ludwigia grandiflora and Myriophyllum aquaticum (Thouvenot et al. 2013), suggesting that such interactions may be species- and/or context-specific. Therefore, it is important to examine the potential interactions between E. canadensis and E. nuttallii where they co-occur in order to ascertain whether impacts on native biota are amplified by the interaction of these species.

Here, we describe two correlational studies which provide insights into the potential impacts of Elodea. Firstly, we used historical data on the macrophyte communities in two 
110 large lakes over the course of an invasion to examine the impact of E. nuttallii on other

111 macrophyte species, and to examine interactions between E. nuttallii and E. canadensis.

112 Secondly, we used a paired survey design to examine differences in micro-algae and

113 invertebrates associated with native macrophytes and invasive E. nuttallii within six

114 waterbodies. We used a combination of standard community metrics (e.g. biomass and

115 species richness) and multivariate analysis of communities, both in terms of taxonomic

116 groups and broader functional or structural groups, to examine impacts at different trophic

117 levels.

\section{Methods}

120 Macrophyte study sites

121 Lough Erne in County Fermanagh, Northern Ireland, comprises Upper Lough Erne (ca. 29

$122 \mathrm{~km}^{2}$ ) and Lower Lough Erne (ca. $\left.104 \mathrm{~km}^{2}\right)$. Lough Erne is a naturally eutrophic lake system

123 with high alkalinity due to the underlying geology of the area. Upper Lough Erne is the 124 shallower of the two lakes with a mean depth of $2.9 \mathrm{~m}$; Lower Lough Erne has a mean depth 125 of $11.9 \mathrm{~m}$. Over the period of this study $\mathrm{pH}$ in these lakes ranged from 6.2 to 9.3 , total 126 phosphorus from $10 \mu \mathrm{g}^{-1}$ to $780 \mu \mathrm{g}^{-1}$ and nitrates from $20 \mu \mathrm{g}^{-1}$ to $1,080 \mu \mathrm{g} \mathrm{l}^{-1}$ (data 127 provided by Northern Ireland Environment Agency (NIEA), based on monthly measurements 128 at ten monitoring points from 2006-2010). Lough Erne is notable for its conservation value, 129 being designated as a Special Area of Conservation (SAC) and Ramsar site and containing 130 many Irish Red Data List species, including the pointed stonewort (Nitella mucronata) and 131 aquatic invertebrates such as the pond skater (Limnoporus rufoscutellatus), water beetles

132 (Donacia aquatica, D. bicolora, Gyrinus distinctus, G. natator and Hydroporus 133 glabriusculus) and white-clawed crayfish (Austropotabius pallipes). E. nuttallii was first recorded in Lough Erne in 2006. 
Field and laboratory methods

137 Data on macrophyte community composition were obtained for both Upper and Lower Lough

138 Erne from the Water Management Unit (WMU), NIEA. These data represent a total of 15 139 transects in Upper Lough Erne during 2007 and 2010 and 18 transects in Lower Lough Erne

140 during 2006 and 2009. Surveys were carried out by wading and by boat depending on water 141 depth. Macrophyte species and percentage cover were recorded within $5 \mathrm{~m}^{2}$ quadrats 142 positioned every $5 \mathrm{~m}$ along each transect perpendicular to the shoreline until the edge of the 143 macrophyte zone was reached. Nitrogen and phosphorus $\left(\mathrm{NO}_{3} \mathrm{~N}, \mathrm{NO}_{2} \mathrm{~N}, \mathrm{NH}_{4} \mathrm{~N}\right.$, Total

144 Organic Nitrogen, soluble P, and Total P) were measured in surface waters in late July or

145 August for each survey year at a central point in Upper Lough Erne and two points in Lower 146 Lough Erne (Fig 1). These chemistry data are included to account for differences between 147 lakes and over time, rather than smaller scale differences between transects. Unfortunately, it 148 was not possible to obtain more detailed information on water chemistry due to the historical 149 nature of the dataset. We have also accounted for this issue by using a paired statistical design 150 which means that we are not comparing quadrats from different parts of the lakes. Only quadrats which were surveyed in both years were used in the analysis ( $n=728$ quadrats).

In order to determine whether the presence of $E$. nuttallii affected the structure of macrophyte beds, each macrophyte species was allocated to one of eight groups based on its

154 structural characteristics: emergent, free-floating, floating rooted, submerged (canopy 155 forming), submerged (low growing), bryophytes, filamentous algae and charophytes.

157 Dissolved oxygen, $p H$, algae and invertebrate study sites

158 A paired survey design of six sites in Northern Ireland was used to examine the associations between E. nuttallii, dissolved oxygen, $\mathrm{pH}$, and algal and invertebrate communities, between 
July and September 2010 (Fig 2.). At each site a native macrophyte stand and a stand of the invader were chosen within the same water body (distance between macrophyte stands $<500$ m). Native species differed between sites, but all had a predominantly submerged habit. Native species and sites were as follows: Potamogeton pectinatus (Lagan), Potamogeton perfoliatus/Myriophyllum spicatum (Ballyronan), Potamogeton natans (Lough Cashel), Ceratophyllum demersum (Loughbrickland and Upper Bann), Sagittaria sagittifolia (Lower Bann). Waterbodies were selected to represent the most common site conditions in which Elodea nuttallii was found and included three lake sites and three slow-flowing river sites. All samples were taken in shallow water between $0.45 \mathrm{~m}$ and $1.05 \mathrm{~m}$ in depth. There was no consistent pattern as to whether E. nuttallii or native plants occurred in deeper water (the mean difference in depth between E. nuttallii and native plants within sites was $14 \mathrm{~cm}$ ). Sites covered a range of nutrient levels from mesotrophic to hypereutrophic (measured total phosphorus ranging from $18 \mu \mathrm{g}^{-1}$ to $1,168 \mu \mathrm{g}^{-1}$ and total dissolved nitrogen between 4.61 $\mu \mathrm{g}^{-1}$ and $\left.530 \mu \mathrm{g}^{-1}\right)$.

Field and laboratory methods

Water chemistry, environmental data and algal sampling took place monthly for 3 months from July to September 2010. The $\mathrm{pH}$ and dissolved oxygen were recorded at each site using a Hanna pHep 4 pH meter and a portable dissolved oxygen meter (VWR DO200). Two litres of water was collected within each macrophyte bed for chlorophyll $a$ analysis, filtered using a

$1800.45 \mu \mathrm{m}$ Metricel ${ }^{\circledR}$ membrane filter and stored at $-20^{\circ} \mathrm{C}$. Chlorophyll $a$ analysis was conducted using methanol-based pigment extraction and spectrophotometry readings (Hamilton, 2010). A further two litres of water was collected for nutrient analyses: soluble reactive phosphorus (SRP), total phosphorus (TP), total soluble phosphorus (TSP), total organic nitrogen $(\mathrm{TON})$, ammonium $\left(\mathrm{NH}_{4}\right)$, nitrogen dioxide $\left(\mathrm{NO}_{2}\right)$, nitrates $\left(\mathrm{NO}_{3}\right)$ and total 
185 dissolved nitrogen (TDN). Nutrient analyses were conducted by the Agri-Food and 186 Biosciences Institute, Newforge Lane, Belfast, Northern Ireland.

187 Algal periphyton was collected by taking approximately $10 \mathrm{~cm}$ length of plant material 188 from both the tip and the base of the macrophyte with approximately $15 \mathrm{ml}$ of water 189 immediately surrounding the macrophyte leaves. Care was taken to carry out this procedure 190 slowly and carefully in situ to minimise loss of periphyton. Water samples were filtered 191 through a $250 \mu \mathrm{m}$ mesh within 10 minutes of sampling to remove zooplankton and preserved 192 using Lugol's Iodine solution (5 g iodine $\left(\mathrm{I}_{2}\right), 10 \mathrm{~g}$ potassium iodide (KI), $85 \mathrm{ml}$ distilled $193 \mathrm{H}_{2} \mathrm{O}$ ). One algal sample was taken in each invaded and each uninvaded macrophyte bed in 194 each of July, August and September. Algal samples were kept in the dark at $5-7^{\circ} \mathrm{C}$ before 195 processing.

196 Algal periphyton was separated from plant samples by vigorous shaking for 60 seconds.

197 The algal sample was then transferred into a sterile $20 \mathrm{ml}$ tube. Plant material was dried at $19860^{\circ} \mathrm{C}$ for 72 hrs and the dry mass was recorded. The algal sample was placed in a Lund 199 chamber. Five horizontal transects of the chamber were carried out at x100 magnification 200 and larger species were identified and counted. A further 20 random fields of view $\left(450 \mu \mathrm{m}^{2}\right)$ 201 were examined at x400 magnification and all species were identified and counted. Taxa were identified to genus level where possible, or to the lowest practical taxonomic level 203 (Bellinger, Sigee 2010; Cox 1996; John et al. 2002). It was not possible to accurately identify 204 all cells under $10 \mu \mathrm{m}$; those which could not be identified were measured for biovolume and 205 recorded as "unidentified genera” (1.9\% of total algal biovolume). For unicellular and 206 colonial algae, the first 10 cells or colonies of each genus or species were measured. For

207 filamentous algae, the first 30 filaments were measured as there was greater variation 208 observed in filament length than in cell or colony size. Mean cell biovolumes were calculated 
using the 'WISER phytoplankton counter spreadsheet' (Carvalho et al. 2007) and biovolume formulae were added for new taxa as defined in Hillebrand et al. (1999).

211 Algal species were categorised into seven functional groups based on Kruk et al. (2010)

212 plus an eighth group of 'uncategorised genera' (Supplementary Material, Table S1). These

213 groups have been proposed to be useful predictors of algal responses to environmental

214 variables as they are closely linked with functional characteristics such as prey avoidance, $K$ and $r$ strategies and sinking rates (Kruk et al. 2010).

Invertebrates were sampled during July and late September/early October using two methods at each sampling date. Firstly, at each site, four replicate core samples of sediment were taken from each macrophyte bed using a KC Denmark Kayak core sampler 45 mm in

219 diameter (hereafter, referred to as 'sediment invertebrate samples'). Secondly, invertebrates present in macrophyte material were collected using a bespoke bucket and mesh trap of 379 $\mathrm{cm}^{2}$ surface area and $300 \mu \mathrm{m}$ mesh size (hereafter, referred to as 'macrophyte invertebrate samples').

Invertebrates were separated from samples using a $250 \mu \mathrm{m}$ sieve and stored in $70 \%$ ethanol. Plant material was dried at $60^{\circ} \mathrm{C}$ for 72 hrs and its dry mass recorded for calculation of macrophyte stand density. All invertebrates were identified to the lowest possible taxonomic level (Edington, Hildrew 1995; Elliott, Mann 1998; Fitter, Manuel 1986; Friday 1998; Gledhill et al. 1993; Savage 1989; Wallace et al. 1990). For sediment invertebrate samples, specimen length, width and dry mass were measured $(n=523)$. Linear regressions based on the length or width and biomass (transformed by $\log _{10}$ or a natural logarithm depending on best fit described by the adjusted $\mathrm{R}^{2}$ value) were conducted using SigmaPlot 10 to describe the relationship between individual length/width and biomass for each common invertebrate family or genus (Supplementary Material, Table S2). In taxa that exhibited a significant relationship between length/width and body mass these regression formulae were 
used to calculate the biomass of individuals of that taxa in the macrophyte invertebrate samples. For all other species dry mass was measured directly. Invertebrate species were further categorised into six functional feeding guilds: collector filterers, collector gatherers, herbivore piercers, predators, scraper grazers and shredders following (Chaloner et al. 2009; Compin, Cereghino 2007; Cummins, Klug 1979; Heino 2008) (Supplementary Material, Table S3).

\section{Statistical analyses}

\section{Macrophytes}

244 In Lough Erne, the impact of Elodea spp. on total macrophyte cover, non-Elodea macrophyte cover and species richness (i.e. native plants) was examined using a Generalized Linear Mixed Model (GLMM) approach. Explanatory variables in the models were Year (fitted as a factor with four levels: 2006, 2007, 2009 or 2010), water depth and nutrient concentration, the percentage cover of E. nuttallii, the percentage cover of E. canadensis, and the interaction of E. nuttallii and E. canadensis. Nutrient concentration was expressed as the first axis of a PCA analysis of nitrogen and phosphorus values, which explained $62.7 \%$ of the variance with a positive relationship with nitrogen variables $(r=0.95)$ and a negative relationship with phosphorus variables $(\mathrm{r}=-0.67)$. Quadrat nested within lake was included as a random factor.

All GLMMs were first fitted with a Gaussian distribution and identity link function. Model residuals were tested for normality using a Shapiro-Wilk test. Models for which residuals were not normally distributed were refitted using alternative distributions more suited to the response data. Specifically, gamma distributions with a log-link function were used for continuous response data and a Poisson distribution with a log link function was 
used for count data (i.e. species richness). In each GLMM, all possible subsets of explanatory variables were ranked using the Akaike Information Criterion adjusted for small sample sizes (AICc), and the most optimal model was taken as that with the lowest AICc value.

Multivariate responses in macrophyte communities were assessed using partial Canonical

264 Correspondence Analysis (pCCA). Two pCCAs were conducted, the first with a response 265 matrix of percentage cover of macrophyte structural groups and a second with percentage cover of macrophyte genera. The associated environmental matrix included the percentage cover of E. nuttallii, E. canadensis, Year (as a factor), water depth and nutrient content. Quadrat was fitted as a random factor. The optimal model was obtained following stepwise forward selection followed by backward stepwise elimination. Explanatory variables were sequentially added to a null model (with site fitted as a random factor) where these variables significantly improved model AICc values based on a permutation test $(P<0.05$ for inclusion), and then successively dropped from the model based on the same inclusion criteria. As E. canadensis was not included in the final pCCA model, it was then added to the response matrices (i.e. plant genera and structural datasets).

In order to assess whether species communities where $E$. nuttallii was present were more similar to each other than those without E. nuttallii, an analysis was carried out on multivariate homogeneity of group dispersion using the function "betadisper" in R based on a Jaccard dissimilarity distance matrix. This was conducted based on a Jaccard dissimilarity distance between species communities (i.e. the proportion of species which differed between quadrats where E. nuttallii was present vs. the proportion of species which differed between quadrats where E. nuttallii was not present). 
285 GLMMs were used to examine all univariate dependent variables in relation to the presence

286

of E. nuttallii. Water chemistry response variables (dissolved $\mathrm{O}_{2}$ saturation, $\mathrm{pH}$ and chlorophyll $a$ ) were tested for correlation prior to GLMM analysis using Spearman's rank correlation test. There was no significant correlation between these variables (dissolved $\mathrm{O}_{2}-$ chlorophyll $a$ (rho $=0.168, P=0.327)$, dissolved $\mathrm{O}_{2}-\mathrm{pH}$ (rho $\left.=0.286, P=0.091\right)$ and chlorophyll $a$ and $\mathrm{pH}$ (rho $=0.086, P=0.617$ ). Explanatory variables for these physiochemical variables were the presence or absence of E. nuttallii and month (July, August or September), waterbody type (i.e. two level factor "Lake" or "River") and the interaction between E. nuttallii presence and waterbody type. Site was fitted as a random factor.

Explanatory variables for GLMMs of algal biovolume, algal species richness and macrophyte bed density were the presence and absence of E. nuttallii, month, waterbody type (i.e. a two level factor "Lake" or "River") and the interaction between E. nuttallii presence and waterbody type, nutrient concentration and the interaction of E. nuttallii and nutrient concentration. Nutrient concentration was expressed as the first axis of a PCA analysis of nitrogen and phosphorus values which explained $64.1 \%$ of the total variance and had a positive relationship with both nitrogen $(r=0.83)$ and phosphorus variables $(r=0.73)$. Site was fitted as a random factor.

Invertebrate richness and biomass in both macrophyte samples and sediment core samples were examined as above for algae. However, macrophyte bed density was added as an explanatory variable to each model. Model selection was as above for previous GLMMs.

Multivariate community responses were assessed using pCCA. Response matrices for algae were biovolume of each algal functional group and biovolume of each algal taxon (per unit of plant dry mass). Response matrices for invertebrate species were the biomass of 
309 invertebrate feeding guilds and biomass of invertebrate taxa. The associated explanatory

310 environmental matrix included the same factors and covariates as those used in univariate

311 analyses i.e., the presence/absence of E. nuttallii, month and nutrient concentrations,

312 waterbody type and the interaction between $E$. nuttallii presence and waterbody type, with

313 the addition of plant density in invertebrate models only. Site was fitted as a random factor.

314 Model optimisation was conducted as previously described for pCCAs of macrophyte 315 communities.

316 In order to assess whether algal and invertebrate communities on E. nuttallii were more

317 similar to each other than those on native plants were to each other we conducted an analysis

318 of multivariate homogeneity of group dispersion using the function "betadisper" in R (as per

319 macrophyte community data).

320 Unless otherwise stated all analyses were performed using R 3.0.2 (R Core Development

321 Team 2012) and the packages glmmADMB (Fournier et al. 2012), MuMIn (Barton 2013)

322 and vegan (Oksanen et al. 2013).

323

324 Results

325

326 Macrophytes

327 Elodea nuttallii was present in $2 \%$ of the 728 quadrats in the initial survey in 2006-07 and 328 increased to presence in $70 \%$ of quadrats in $2009-10$. Over the same period, the percentage 329 cover of $E$. nuttallii within each quadrat increased from a mean of $0.03 \%(0-4 \%)$ to $21.3 \%$ $330(0-100 \%)$ on resurvey in 2009-10. E. canadensis declined in presence from 33\% to $9 \%$ of 331 quadrats and in mean cover per quadrat from $1.1 \%(0 \%-70 \%)$ to $0.5 \%(0 \%-30 \%)$ over the 332 same period. A total of 71 other macrophyte species was recorded. E. canadensis and E. 333 nuttallii were the only invasive species recorded in these surveys. 
Total macrophyte cover within quadrats was positively associated with cover of both $E$. nuttallii $\left(\beta=0.013 \pm 0.003, \chi^{2}=20.24, P<0.001\right)$ and E. canadensis $\left(\beta=0.029 \pm 0.012, \chi^{2}\right.$

$336=5.53, P=0.019)$. Excluding both Elodea species from the total macrophyte cover, the 337 cover of remaining species was not significantly associated with the cover of either $E$. nuttallii or E. canadensis, but declined with water depth and differed between years. Both total macrophyte cover and the cover of non-Elodea species were negatively associated with water depth, the PCA axis of nutrient concentration and differed between years (see Supplementary Material, Table S5).

Species richness of macrophytes other than E. nuttallii and E. canadensis (i.e. native species) was positively associated with percentage cover of both $E$. nuttallii $(\beta=0.002 \pm$ $\left.0.001, \chi^{2}=3.85, P=0.050\right)$ and $E$. canadensis $\left(\beta=0.013 \pm 0.004, \chi^{2}=11.58, P<0.001\right)$ and with the PCA axis of nutrient concentrations and negatively associated with water depth and differed between years (see Supplementary Material, Table S5). There was no evidence of an interaction between E. canadensis and E. nuttallii in any model.

The pCCA of macrophyte structural groups showed that year and percentage cover of $E$. nuttallii influenced structural composition and explained $4.6 \%$ of the variation in plant structure after variation between quadrats $(69 \%)$ was accounted for $(P<0.005$; Fig. 3$)$. The pCCA of macrophyte genera showed that water depth, year and percentage cover of $E$. nuttallii influenced composition of genera significantly and explained 3.9\% of the variation after between-quadrat variation (53.9\%) was accounted for $(P<0.005)$. The percentage cover of $E$. nuttallii alone (with the other factors accounted for by pCCA) explained only $0.6 \%$ and $0.5 \%$ of the variation in structural groups and genera respectively $(P<0.033$ and $P<0.005$ respectively; Supplementary Material, Table S6). The cover of submersed low-growing species and charophytes was negatively associated with the cover of E. nuttallii, whilst the surface-growing plants (both free-floating and rooted) were positively associated with $E$. 
nuttallii (Table 1). At a taxonomic level, the most negatively affected species was $E$. canadensis whilst Nuphar lutea and Stratiotes aloides were most positively associated (Table variance between quadrats and between years (Tables 1, 2).

Analysis of multivariate homogeneity of group dispersion showed that quadrats containing E. nuttallii were more homogeneous (mean Jaccard dissimilarity $=0.43$, s.e. $<$ 0.01) than those that did not contain E. nuttallii (mean Jaccard dissimilarity $=0.49$, s.e. $<$ 0.01) $(F=24.34, P<0.001)$.

Dissolved oxygen, $\mathrm{pH}$, algae and invertebrates

Dissolved $\mathrm{O}_{2}$ saturation differed between lakes and rivers being higher in lakes than in rivers.

370

371 The presence of $E$. nuttallii was included in the best model of dissolved $\mathrm{O}_{2}$ saturation $\left(\chi^{2}=\right.$ 3.21, $P=0.073$ ), being higher in E. nuttallii stands (mean \pm s.e. $=93.97 \% \pm 5.46$ ) than in native plant stands $(85.13 \% \pm 3.86)$. Chlorophyll $a$ showed no significant association with rivers or lakes, months or the presence of $E$. nuttallii. The $\mathrm{pH}$ varied significantly between months, but was not significantly associated with the presence of E. nuttallii (Supplementary Material, Table S7).

Macrophyte bed density did not differ between E. nuttallii and native macrophyte beds and was not associated with any of the other variables tested. The optimal model for algal species richness contained $E$. nuttallii with marginal significance $\left(\chi^{2}=3.67, P=0.055\right)$ and month, but not nutrient concentration. Algal biovolume per gram of plant dry mass varied significantly between months. Algal biovolume was not affected by either the presence of $E$. nuttallii or nutrient concentration (Supplementary Material, Table S8).

The pCCA of algal community data showed no significant effect of E. nuttallii on algal community composition in terms of either functional groups or taxa. The community 
composition in terms of algal functional groups was not significantly associated with any of

385

386

387

388

389

390

391

392

393

394

395

396

397

398

399

400

401

402

403

404

405

406

407

408 the explanatory variables tested. However, nutrient concentration and month significantly affected community composition in terms of algal taxa $(P=0.015)$. Analysis of multivariate homogeneity of group dispersion did not show any significant difference in the variance between algal communities on $E$. nuttallii and those on native plants $(F=0.42, P=0.521)$.

None of the community metrics of invertebrate species on macrophytes or sediment differed between E. nuttallii and native macrophyte samples. Invertebrate species richness, derived from macrophyte samples, varied significantly between months. Invertebrate biomass in macrophyte samples also varied significantly between months and was positively correlated with plant density and nutrient concentration. Invertebrate species richness in sediment cores was not significantly associated with any of the environmental parameters. Invertebrate biomass in the sediment cores was positively associated with nutrient, but not with any of the other environmental parameters (Supplementary Material, Table S9).

The pCCAs of invertebrate taxonomic communities sampled from macrophytes showed a significant effect of the interaction of waterbody type and the presence of E. nuttallii, suggesting that the impact of $E$. nuttallii on invertebrate communities differed between lakes and rivers. This interaction explained $10 \%$ of the variation in invertebrate communities $(P=$ $0.043)$ after variation between sites $(45 \%)$ was accounted for $(P=0.005)$. When rivers and lakes were examined separately, E. nuttallii was found to explain $9 \%$ of variation in invertebrate communities in lakes and $13 \%$ of the variation in rivers, after accounting for variation between sites ( $41 \%$ and 33\% respectively; Tables 3 \& 4, Fig. 3). The pCCAs of invertebrate functional groups from the macrophyte invertebrate samples and the pCCAs of invertebrate community in sediment core samples showed no association with any of the tested variables after accounting for variation between sites (Supplementary Material, Table S10). In addition, analysis of multivariate homogeneity of group dispersion did not show any 
409 significant difference in the variance between invertebrate communities associated with $E$.

410 nuttallii stands and those associated with native plant stands in either macrophyte $(F=0.15$,

$411 P=0.702)$ or sediment samples $(F=1.92, P=0.179)$.

412

\section{Discussion}

415 Freshwater communities associated with Elodea nuttallii differed in small but significant

416 ways from uninvaded communities. Specifically, we observed differences in oxygen 417 saturation, plant and algal richness, and invertebrate and macrophyte species composition.

418 However, observed differences were small relative to other factors such as nutrient levels,

419 inter-annual variation and differences between sites. Furthermore, there was no evidence of

420 any effect of $E$. nuttallii on the biovolume of periphytic algae, biomass of invertebrate

421 species or the cover of native macrophyte species. In addition, whilst plant communities in

422 quadrats containing E. nuttallii were more similar to each other than quadrats in which $E$.

423 nuttallii was not present, no similar effect was observed on algal or invertebrate 424 communities.

425 The effects of E. nuttallii on species communities could be seen as both positive and 426 negative, for example, the increased species richness of macrophyte species may be 427 contrasted with the lower richness of algal taxa. Increases in floating plants associated with 428 E. nuttallii can be contrasted with declines in submerged species. The association between 429 floating plant species and E. nuttallii may arise as a result of structural complexity where E. 430 nuttallii reaches the water surface, which reduces surface turbidity and provides anchorage 431 for floating species. In addition, floating species are most likely to out-compete E. nuttallii 432 for light and have been shown to out-compete E. nuttallii in high nutrient conditions (Netten 433 et al. 2010; Szabo et al. 2010). Submerged species which are negatively associated include 
434 low-growing species which are likely to be shaded by E. nuttallii (such as Eleocharis

435

436

437

438

439

440

441

442

443

444

445

446

447

448

449

450

451

452

453

454

455

456

457

458

acicularis, Isoetes spp., Littorella uniflora), canopy-forming submerged species occupying a similar niche space to E. nuttallii (including E. canadensis) and charophyte species.

Although the observed negative association between E. nuttallii and charophytes is small, this is of concern due to the rarity and conservation status of charophyte species. Charophytes are usually low-growing ( $<0.5 \mathrm{~m}$ in height) and are likely to be out-competed for light by $E$. nuttallii. While this negative association could arise in this study from charophytes reducing the likelihood of establishment of $E$. nuttallii, this seems unlikely as charophytes have been previously shown to be out-competed by structurally similar invaders from the same plant family (e.g. Lagarosiphon major (Barrs et al. 2008) and E. canadensis (Mjelde et al. 2012)).

The observed negative association between the cover of E. nuttallii and E. canadensis suggests a competitive interaction between these two closely related invasive species. We did not find any indication that E. nuttallii or E. canadensis interact to increase impacts on native macrophyte cover or richness. Therefore, our findings do not support the invasion meltdown hypothesis in the case of E. nuttallii and E. canadensis. In addition, the observed rapid increase range and abundance of E. nuttallii in Lough Erne (such that it is much now much more frequently observed than E. canadensis), supports the suggestion that E. nuttallii may be replacing E. canadensis in parts of its invaded range (Barrat-Segretain et al. 2001; BarratSegretain, 2002).

It is perhaps surprising that species richness of native macrophytes was positively associated with the presence of E. nuttallii and E. canadensis in Lough Erne, after differences in nutrient levels and between years had been accounted for. Mechanisms for facilitation of native plant species could include alteration of flow rate and turbidity, or increases in primary productivity over time through the release of nutrients from the sediment. However, these alterations could also make conditions suitable for further establishment of $E$. nuttallii, which 
can absorb nutrients directly from the water column and is adapted to low-light conditions

460 (Angelstein, Schubert 2008, 2009). An alternative explanation for the positive correlation

461 between $E$. nuttallii and species richness of native macrophytes is that some other

462 environmental factor, unaccounted for here, facilitates both an increase in E. nuttallii cover/or

463 its establishment and macrophyte species richness. Previous studies have suggested that while

464 species richness increases resistance to invasion at small spatial scales (Kennedy et al. 2002),

465 such effects may be overwhelmed by environmental factors which co-vary with species

466 richness, such as propagule pressure, resulting in an apparent positive relationship between

467 invasive species and native species richness (Levine 2000; Lonsdale 1999). Furthermore, a

468 recent large-scale study of invasive species in macrophyte communities found no clear

469 relationship between native species richness and exotic species richness (Capers et al. 2007).

470 In common with previous authors we found that plant density was significantly correlated

471 with the biomass of invertebrate species living on macrophytes (Schultz, Dibble 2012).

472 However, in our study plant density and invertebrate biomass did not differ between $E$.

473 nuttallii and native plants, reflecting an explicit decision to examine differences between

474 similar native and invasive plant beds. Whilst E. nuttallii may not alter the biomass of

475 invertebrate species relative to similar-sized plants, results from our macrophyte dataset

476 suggest that E. nuttallii may be replacing low-growing species and increasing overall

477 macrophyte cover. Hence, by altering the relative regional abundance of different plant

478 functional groups, E. nuttallii may produce corresponding changes in invertebrate biomass at

479 larger spatial scales.

480 Differences in invertebrate assemblages associated with macrophytes have also been 481 shown previously for similar submerged invasive species (Hogsden et al. 2007; Kelly, Hawes 482 2005; Stiers et al. 2011). The reasons for the observed differences in invertebrate species 483 composition may be varied and complex, and are likely to relate to differences in plant 
architecture, plant palatability, chemical exudates, water chemistry and water flow rates.

485 Oxygen saturation is an important factor in determining invertebrate communities in

486

487

488

489

490

491

492

493

494

495

496

497 freshwater environments. Higher oxygen saturation levels associated with E. nuttallii may have influenced species composition here: there was a lower abundance of some species groups associated with low oxygen saturation levels such as true fly larvae in the family Chironomidae, Alderflies (Sialis lutaria), leeches in the genera Erpobdella and Theromyzon, and Asellus amphipods, and a higher abundance of some species associated with higher oxygen saturation such as caddisflies in the family Linephiidae. However, several species behaved contrary to expectation based on oxygen saturation alone, suggesting that other factors influence their distributions, for example damselflies in the family Coengriidae were negatively associated with $E$. nuttallii, leeches in the family Glossiphonidae were positively associated with E. nuttallii, and freshwater snails in the genera Hippeautis, Lymnea, Valvata, Physa and Bithynia, which have similar oxygen requirements, show a range of different responses. Allelopathy may explain observed negative association between E. nuttalii and lepidopteran larvae in the family Pyralidae, as E. nuttalii has been previously shown to retard the growth and reduce the survival of the Pyralidae species Acentria ephemerella under laboratory conditions (Erhard et al. 2007). Where Pyralidae larvae exist in large numbers they may substantially reduce cover of other macrophyte species providing an indirect advantage to Elodea spp. (Gross et al. 2001).

One weakness of the pairing of native and invasive plant beds in this study was that it was not possible to use sites where only E. nuttallii was present (i.e. highly invaded sites). Therefore, if native species are required at particular points in invertebrate life cycles (e.g. reproduction), population declines associated with their absence may not have been detected as invertebrate species could move between plant beds if necessary. Additionally, many Northern Irish water bodies, such as those sampled here, have been subject to considerable 
509 pressure from eutrophication, pollution and human disturbance, especially in lowland areas

510 (Heegaard et al. 2001) prior to the introduction of invasive species, such as E. nuttallii. The

511 algal and invertebrate communities present in these waterbodies differ from those in more

512 pristine sites, especially in the relative lack of rare species. Impacts of invasive macrophytes

513 may also differ depending on trophic status of waterbodies (Strayer 2010) and in some cases

514 the same invasive macrophyte species has opposite effects on invertebrates in different study

515 systems (Schultz, Dibble 2012). Therefore, it is possible that the impact of E. nuttallii on

516 invertebrate and algal communities would have been different in oligotrophic sites or more

517 pristine sites which had not been previously impacted by anthropogenic pressures.

518 Together these field studies provide insights into the potential impacts of the widespread

519 invader Elodea nuttallii on a range of taxa in temperate waterbodies. Due to the correlational

520 nature of these studies it is not possible to determine cause-and-effect or to reveal the exact

521 drivers of change in biological communities. Here, where possible we have used closely

522 paired sites within waterbodies to minimise potentially confounding differences between

523 sites. We suggest that the results of this research may be used to direct further research

524 including both field and laboratory experiments focused on the interaction of E. nuttallii with

525 particular species of concern (e.g. the observed negative association of E. nuttallii and 526 charophytes).

527 In conclusion, our findings suggest that whilst E. nuttallii significantly altered freshwater

528 communities, observed differences were small relative to other factors such as nutrient levels,

529 inter-annual variation and differences between sites. In addition, we add to a growing body of

530 literature that suggests that the impacts of aquatic invasive plant species are not consistently

531 negative and they may, for example, increase the richness of native plant species or the

532 abundance of invertebrate species if total plant biomass increases as a result of invasion

533 (Schultz, Dibble 2012; Strayer 2010; Thomaz et al. 2012). 


\section{Acknowledgements}

536 This research was funded by the Natural Heritage Research Partnership (NHRP) between the

537 Northern Ireland Environment Agency (NIEA) and Quercus, Queen’s University Belfast 538 (QUB) under a PhD studentship (QU08-05). Water chemistry analyses for the field study

539 were conducted by the Agri-Food and Biosciences Institute, Newforge Lane, Belfast. Data

540 from Lough Erne surveys were kindly supplied by Brenda Walker of the NIEA. Thanks to

541 Irena Tománková for her assistance with invertebrate identification. We also thank our NIEA

542 client officers, John Early and Tony Waterman, for their support. Thanks also to two

543 anonymous reviewers whose advice substantially improved this manuscript.

544 


\section{References}

Angelstein S, Schubert H (2008) Elodea nuttallii: uptake, translocation and release of phosphorus. Aquat Biol 3:209-216

Angelstein S, Schubert H (2009) Light acclimatisation of Elodea nuttallii grown under ambient DIC conditions. Plant Ecol 202:91-101

Barrat-Segretain M (2005) Competition between invasive and indigenous species: impact of spatial pattern and developmental stage. Plant Ecol 180:153-160

Barrs JR, Keenan EA, O'Callaghan P, Caffrey J (2008) Research and control programme for Lagarosiphon major (Hydrocharitaceae). Central Fisheries Board, Ireland

Barton K (2013) MuMIn: Multi-model inference. R package version 1.9.11.

Bellinger EG, Sigee DC (2010) Freshwater algae: identification and use as bioindicators. Wiley-Blackwell, UK

Burks R, Lodge D (2002) Cued in: Advances and opportunities in freshwater chemical ecology. Journal of Chem Ecol 28:1901-1917

Caffrey JM, Baars J-R, Barbour JH, Boets P, Boon P, Davenport K, Dick, J, Early, J, Edsman L, Gallagher C, Gross J, Heinimaa P, Horrill C, Hudin S, Hulme PE, Hynes S, MacIsaac HJ, McLoone P, Millane M, Moen, TL, Moore N, Newman J, O’Conchuir R, O’Farrell M, O’Flynn Colette, Oidtmann B, Renals T, Ricciardi A, Roy H, Shaw R, van Valkenburg JLCH, Weyl Olaf, Williams F, Lucy FE (2014) Tackling invasive alien species in Europe: the top 20 issues. Manag Biol Invasion 5:1-20

Capers RS, Selsky R, Bugbee GJ, White JC (2007) Aquatic plant community invasibility and scale-dependent patterns in native and invasive species richness. Ecology 88:3135-3143

Carniatto N, Thomaz SM, Cunha ER, Fugi R, Ota RR (2013) Effects of an invasive alien Poaceae on aquatic macrophytes and fish communities in a neotropical reservoir. Biotropica 45:747-754

Carvalho L, Dudley B, Dodkins I, Clarke R, Jones I, Thackeray S, Maberly S (2007) Final report project WFD80 Phytoplankton classification tool (Phase 2). SNIFFER, Edinburgh

Chaloner DT, Hershey AE, Lamberti GA (2009) Benthic invertebrate fauna. Elsevier, New York

Champion PD, Clayton JS, Hofstra DE (2010) Nipping aquatic plant invasions in the bud: weed risk assessment and the trade. Hydrobiologia 656:167-172

Compin A, Cereghino R (2007) Spatial patterns of macroinvertebrate functional feeding groups in streams in relation to physical variables and land-cover in Southwestern France. Landscape Ecol 22:1215-1225 
602

603

604

605

606

607

608

609

610

611

612

613

614

615

616

617

618

619

620

621

622

623

624

625

626

627

628

629

630

631

632

633

634

635

636

637

638

639

640

641

642

643

Cox EJ (1996) Identification of freshwater diatoms from live material. Chapman and Hall, London

Cummins KW, Klug MJ (1979) Feeding ecology of stream invertebrates. Annu Rev Ecol Syst 10:147-172

DAISIE (2015) 100 of the worst. http://www.europe-aliens.org/speciesTheWorst.do Accessed 16 January 2015

Declerck S, Vanderstukken M, Pals A, Muylaert K, de Meester L (2007) Plankton biodiversity along a gradient of productivity and its mediation by macrophytes. Ecology 88:2199-2210

deWinton MD, Clayton JS (1996) The impact of invasive submerged weed species on seed banks in lake sediments. Aquat Bot 53:31-45

Edington JM, Hildrew AG (1995) Sp. 53 Caseless cadis larvae (Trichoptera) A revised key to the caseless cadis larvae of the British Isles, with notes on their ecology. Freshwater Biological Association, Ambleside

Elliott JM, Mann KH (1998) Sp. 40 Leeches. A key to the British Freshwater Leeches, with notes on their life cycles and ecology. Freshwater biological association, Ambleside

Erhard D, Pohnert G, Gross EM (2007) Chemical defense in Elodea nuttallii reduces feeding and growth of aquatic herbivorous Lepidoptera. J Chem Ecol 33:1646-1661

Evangelista HBA, Thomaz SM, Umetsu CA (2014) An analysis of publications on invasive macrophytes in aquatic ecosystems. Aquatic Invasions 9:521-528

Fitter R, Manuel R (1986) Field guide to lakes, rivers, streams and ponds of north-west Europe. Harper Collins, Hong Kong

Fournier D, Skaug H, Ancheta J, Ianelli J, Magnusson A, Maunder MN, Nielsen A, Sibert J (2012) AD Model Builder: using automatic differentiation for statistical inference of highly parameterized complex nonlinear models. Optimization Methods \& Software 27:233-249

Friday LE (1998) A key to the adults of British water beetles. Journal of the Field Studies Council 7:1-152

Gledhill T, Sutcliffe DW, Williams WD (1993) British freshwater Crustacea Malacostraca: a key with ecological notes. Freshwater Biological Association, Cumbria

Gross EM, Johnson RL, Hairston NG (2001) Experimental evidence for changes in submersed macrophyte species composition caused by the herbivore Acentria ephemerella (Lepidoptera). Oecologia 127:105-114

Hamilton SK, Lewis WM, Sippel SJ (1992) Energy-sources for aquatic animals in the Orinoco River floodplain - evidence from stable isotopes. Oecologia 89:324-330 
665

666

667

668

669

670

671

672

673

674

675

676

677

678

679

680

681

682

683

684

685

686

687

688

689

690

691

Heegaard E, Birks H, Gibson C, Smith, SJ, Wolfe-Murphy, S (2001) Species-environmental relationships of aquatic macrophytes in Northern Ireland. Aquat Bot 70:175-223

Heino J (2008) Patterns of functional biodiversity and function-environment relationships in lake littoral macroinvertebrates. Limnol Oceanogr 53:1446-1455

Hillebrand H, Durselen C, Kirschtel D, Pollingher U, Zohary T (1999) Biovolume calculation for pelagic and benthic microalgae. J Phycol 35:403-424

Hogsden K, Sager E, Hutchinson T (2007) The impacts of the non-native macrophyte Cabomba caroliniana on littoral biota of Kasshabog Lake, Ontario. J Great Lakes Res 33:497-504

Hulme PE (2012) Weed risk assessment: a way forward or a waste of time? J Appl Ecol 49:10-19

Hussner A (2012) Alien aquatic plant species in European countries. Weed Res 52:297-306

James C, Eaton J, Hardwick K (1999) Competition between three submerged macrophytes, Elodea canadensis Michx, Elodea nuttallii (Planch.) St John and Lagarosiphon major (Ridl.) moss. Hydrobiologia 415:35-40

John DM, Whitton BA, Brook AJ (2002) The freshwater algal flora of the British Isles: An identification guide to freshwater and terrestrial algae. Cambridge University Press, UK

Kelly D, Hawes I (2005) Effects of invasive macrophytes on littoral-zone productivity and foodweb dynamics in a New Zealand high-country lake. J N Am Benthol Soc 24:300320

Kelly R, Leach K, Cameron A, Maggs CA, Reid, N (2014a) Combining global climate and regional landscape models to improve prediction of invasion risk. Divers distrib 20, 884-894

Kelly R, Lundy MG, Mineur F, Harrod C, Maggs CA, Humphries NE, Sims DW, Reid N (2014b) Historical data reveal power-law dispersal patterns of invasive aquatic species. Ecography 37:581-590

Kennedy T, Naeem S, Howe K, Knops JMH, Tilman D, Reich P (2002) Biodiversity as a barrier to ecological invasion. Nature 417:636-638

Kornijow R, Vakkilainen K, Horppila J, Luokkanen E, Kairesalo T (2005) Impacts of a submerged plant (Elodea canadensis) on interactions between roach (Rutilus rutilus) and its invertebrate prey communities in a lake littoral zone. Freshwater Biol 50:262276

Kovalenko KE, Dibble ED (2014) Invasive macrophyte effects on littoral trophic structure and carbon sources. Hydrobiologia 721:23-34 
Kruk C, Huszar V, Peeters E, Bonilla S, Costa L, Lurling M , Reynolds CS , Scheffer M (2010) A morphological classification capturing functional variation in phytoplankton. Freshwater Biol 55:614-627

Leung B, Roura-Pascual N, Bacher S, Heikkila J, Brotons L, Burgman MA, Dehnen-Schmutz K,Essl F, Hulme PE, Richardson DM, Sol D, Vila M (2012) TEASIng apart alien species risk assessments: a framework for best practices. Ecol Lett 15:1475-1493

Levine J (2000) Species diversity and biological invasions: Relating local process to community pattern. Science 288:852-854

Lonsdale W (1999) Global patterns of plant invasions and the concept of invasibility. Ecology 80:1522-1536

Michelan T, Thomaz S, Mormul R, Carvalho P (2010) Effects of an exotic invasive macrophyte (tropical signalgrass) on native plant community composition, species richness and functional diversity. Freshwater Biol 55:1315-1326

Mjelde M, Lombardo P, Berge D, Johansen SW (2012) Mass invasion of non-native Elodea canadensis Michx. in a large, clear-water, species-rich Norwegian lake - impact on macrophyte biodiversity. Int J Limnol 48:225-240

Montgomery WI, Lundy MG, Reid N (2012) 'Invasional meltdown': evidence for unexpected consequences and cumulative impacts of multispecies invasions. Biol Invasions 14:1111-1125

Netten J, Arts G, Gylstra R, Roijackers RMM (2010) Effect of temperature and nutrients on the competition between free-floating Salvinia natans and submerged Elodea nuttallii in mesocosms. Fund and Appl Limnol 177:125-132

O'Hare M, Gunn I, Chapman D, Dudley BJ, Purse BV (2012) Impacts of space, local environment and habitat connectivity on macrophyte communities in conservation lakes. Divers Distrib 18:603-614

Oksanen J, Blanchet FG, Kindt R, Legendre, P, Minchin PR,O'Hara RB, Simpson GL, Solymos P, Stevens MHH, Wagner, Helene (2013) vegan: Community Ecology Package. R package version 2.0-9.

R Core Development Team (2012) R: A language and environment for statistical computing. R Foundation for Statistical Computing, Vienna, Austria

Rybicki N, Landwehr J (2007) Long-term changes in abundance and diversity of macrophyte and waterfowl populations in an estuary with exotic macrophytes and improving water quality. Limnol Oceanogr 52:1195-1207

Sala OE, Chapin III FS, Armesto JJ, Berlow Eric, Bloomfield J, Dirzo R, Huber-Sanwald E, Huenneke LF, Jackson RB, Kinzig A, Leemans R, Lodge DM, Mooney HA, Oesterheld M, Poff, NL, Sykes, MT, Walker, BH, Walker M, Wall DH (2000) Global biodiversity scenarios for the year 2100. Science 287:1770-4 
Savage AA (1989) Adults of the British Aquatic Hemiptera Heteroptera: a Key with Ecological Notes. Freshwater Biological Association, Ambleside, UK

Schultz R, Dibble E (2012) Effects of invasive macrophytes on freshwater fish and macroinvertebrate communities: the role of invasive plant traits. Hydrobiologia 684:114

Simberloff D (2006) Invasional meltdown 6 years later: important phenomenon, unfortunate metaphor, or both? Ecol Lett 9:912-919

Stiers I, Crohain N, Josens G, Triest L (2011) Impact of three aquatic invasive species on native plants and macroinvertebrates in temperate ponds. Biol Invasions 13:2715-2726

Strayer D (2010) Alien species in fresh waters: ecological effects, interactions with other stressors, and prospects for the future. Freshwater Biol 55:152-174

Szabo S, Scheffer M, Roijackers R, Waluto B, Braun M, Nagy PT, Borics G, Zambrano L (2010) Strong growth limitation of a floating plant (Lemna gibba) by the submerged macrophyte (Elodea nuttallii) under laboratory conditions. Freshwater Biol 55:681-690

Thiébaut G, Di Nino F, Peltre M-C, Wagner, P (2008) Management of Aquatic Exotic Plants: The Case of Elodea Species. In: Sengupta M and Dalwani R (eds) The $12^{\text {th }}$ World Lake Conference. Taal, pp. 1058-1066

Thomaz SM, Silveira MJ, Michelan TS (2012) The colonization success of an exotic Poaceae is related to native macrophyte richness, wind disturbance and riparian vegetation. Aquat Sci 74:809-815

Thouvenot L, Puech C, Martinez L, Haury J,Thiebaut G (2013) Strategies of the invasive macrophyte Ludwigia grandiflora in its introduced range: Competition, facilitation or coexistence with native and exotic species? Aquat Bot 107:8-16

Valinoti C, Ho C, Armitage A (2011) Native and exotic submerged aquatic vegetation provide different nutritional and refuge values for macroinvertebrates. J Exp Mar Biol Ecol 409:42-47

Wallace ID, Wallace B, Philipson GN (1990) A key to the case-bearing caddis larvae of Britain and Ireland. Freshwater Biological Association, Ambleside, UK

Warfe DM, Barmuta LA (2006) Habitat structural complexity mediates food web dynamics in a freshwater macrophyte community. Oecologia 150:141-154 
785 Table 1. Results of partial Canonical Correspondence Analysis (pCCA) of macrophyte

786 structural groups, showing orthogonal species scores when Elodea nuttallii is fitted as the

787 explanatory variable and quadrat and year are accounted for by partial CCA; variance

788 explained by percentage cover of Elodea nuttallii, variance explained by year and the

789 variance explained by the full model (i.e. Elodea nuttallii, year and quadrat).

\begin{tabular}{lcccc}
\hline & $\begin{array}{c}\text { CCA scores } \\
\text { against only } \\
\text { Elodea } \\
\text { nuttallii }\end{array}$ & $\begin{array}{c}\text { Variance } \\
\text { explained by } \\
\text { Elodea nuttallii } \\
\mathbf{( \% )}\end{array}$ & $\begin{array}{c}\text { Variance } \\
\text { explained } \\
\text { by year } \\
\mathbf{( \% )}\end{array}$ & $\begin{array}{c}\text { Variance } \\
\text { explained by } \\
\text { full model (\%) }\end{array}$ \\
\hline Submersed low-growing & -0.60 & 0.25 & 0.45 & 52.70 \\
Charophytes & -0.28 & 0.50 & 10.55 & 63.50 \\
Emergent & -0.16 & 1.12 & 0.67 & 87.12 \\
Filamentous algae & 0.04 & 0.13 & 3.80 & 88.26 \\
Submersed canopy-forming & 0.04 & 0.15 & 4.57 & 89.21 \\
Bryophytes & 0.17 & 0.06 & 1.41 & 74.78 \\
Floating-rooted species & 0.43 & 0.96 & 0.41 & 48.18 \\
Free-floating & 0.47 & 1.77 & 2.98 & 79.45 \\
\hline
\end{tabular}


792 Table 2. Results of partial Canonical Correspondence Analysis (pCCA) for the genera most 793 strongly associated with Elodea nuttallii. Genera with greater than $0.5 \%$ of variation 794 explained by Elodea nuttallii are shown. Table shows species from each genus present in the 795 dataset, species scores when Elodea nuttallii is fitted as the explanatory variable and depth, 796 quadrat location and year are accounted for by partial CCA, variance explained by percentage 797 cover of Elodea nuttallii, variance explained by depth and year, and the variance explained 798 by the full model.

799

\begin{tabular}{|c|c|c|c|c|c|}
\hline Genus/Family & Species & $\begin{array}{c}\text { CCA scores } \\
\text { against only } \\
\text { Elodea } \\
\text { nuttallii } \\
\end{array}$ & $\begin{array}{c}\text { Variance } \\
\text { explained by } \\
\text { Elodea } \\
\text { nuttallii (\%) }\end{array}$ & $\begin{array}{c}\text { Variance } \\
\text { explained by } \\
\text { depth and } \\
\text { year }(\%) \\
\end{array}$ & $\begin{array}{c}\text { Variance } \\
\text { explained } \\
\text { by full } \\
\text { model }(\%)\end{array}$ \\
\hline Elodea & E. canadensis & -0.77 & 3.01 & 4.12 & 74.99 \\
\hline Juncus & J. bulbosus & -0.65 & 0.80 & 4.08 & 61.64 \\
\hline Sparganium & $\begin{array}{l}\text { S. emersum } \\
\text { S. erectum }\end{array}$ & -0.32 & 0.54 & 0.57 & 69.87 \\
\hline *Characeae & $\begin{array}{l}\text { Chara globularis } \\
\text { Chara vulgaris } \\
\text { Nitella flexilis agg. } \\
\text { Nitella translucens }\end{array}$ & -0.32 & 0.65 & 10.68 & 63.77 \\
\hline Equisetum & $\begin{array}{l}\text { E. fluviatile } \\
\text { E. palustre }\end{array}$ & -0.30 & 0.68 & 5.55 & 77.02 \\
\hline Potamogeton & $\begin{array}{l}\text { P. alpina } \\
\text { P. crispus } \\
\text { P. filiformis } \\
\text { P. friesii } \\
\text { P. lucens } \\
\text { P. natans } \\
\text { P. obtusifolius } \\
\text { P. pectinatus } \\
\text { P. perfoliatus } \\
\text { P. praelongus } \\
\text { P. pusillus } \\
\text { P. trichoides } \\
\text { P. zizii }\end{array}$ & 0.10 & 0.67 & 2.16 & 89.54 \\
\hline Nuphar & N. lutea & 0.44 & 0.94 & 1.25 & 47.75 \\
\hline Nymphaea & N. alba & 0.94 & 0.54 & 2.63 & 45.54 \\
\hline Stratiotes & S. aloides & 1.60 & 4.75 & 8.16 & 73.69 \\
\hline
\end{tabular}

* Characeae were analysed at a family level as 2006 and 2007 surveys did not record at a species level within this family 
800 Table 3. Results of partial Canonical Correspondence Analysis (pCCA) of invertebrate taxa

801 living on macrophytes in lakes. Taxanomic groups which were present in more than one

802 sample and for which $>0.5 \%$ of variation is explained by Elodea nuttallii are shown. Table

803 details taxa scores when Elodea nuttallii is fitted as the explanatory variable, variance

804 explained by percentage cover of Elodea nuttallii, and the variance explained by the full

805 model.

806

\begin{tabular}{|c|c|c|c|c|c|}
\hline Taxa & Species present & Order & $\begin{array}{c}\text { CCA scores } \\
\text { against Elodea } \\
\text { nuttallii only } \\
\end{array}$ & $\begin{array}{c}\text { Variance explained } \\
\text { by Elodea nuttallii } \\
(\%)\end{array}$ & $\begin{array}{c}\text { Variance } \\
\text { explained by full } \\
\text { model (\%) } \\
\end{array}$ \\
\hline Pyralidae & Spp. & Lepidoptera & -2.21 & 27.29 & 32.27 \\
\hline Hydrachna & Spp. & Trombidiformes & -1.47 & 17.93 & 57.90 \\
\hline Coenagrionidae & Spp. & Odonata & -1.27 & 5.47 & 9.03 \\
\hline Erpobdella & $\begin{array}{l}\text { E. octoculata } \\
\text { E. testacea }\end{array}$ & Rhynchobdellida & -1.25 & 20.00 & 55.60 \\
\hline Chironomidae & Spp. & Diptera & -1.16 & 38.42 & 45.23 \\
\hline Rhyacophila & Spp. & Trichoptera & -0.92 & 0.65 & 37.26 \\
\hline Physa & P. fontinalis & *Planorboidea & -0.74 & 5.01 & 17.72 \\
\hline Lymnaea & $\begin{array}{l}\text { L. auricularia } \\
\text { L. palustris } \\
\text { L. peregra }\end{array}$ & Lymnaea & -0.70 & 6.23 & 33.01 \\
\hline Gyraulus & G. albus & *Planorboidea & 0.34 & 1.25 & 24.87 \\
\hline Crangonyx & C. pseudogracilis & Amphipoda & 0.37 & 1.70 & 17.04 \\
\hline Sialis & S. lutaria & Megaloptera & 0.77 & 2.56 & 46.89 \\
\hline Bithynia & B. tentaculata & *Truncatelloidea & 0.98 & 8.56 & 49.57 \\
\hline Cortixinae & Spp. & Hemiptera & 1.22 & 9.30 & 49.01 \\
\hline Valvata & $\begin{array}{l}V . \text { cristata, } \\
V . \text { piscinalis }\end{array}$ & *Valvatoidea & 1.94 & 11.46 & 33.69 \\
\hline Limnephilidae & Spp. & Trichoptera & 2.03 & 26.19 & 45.12 \\
\hline Hippeutis & H. complanatus & Gastropoda & 2.05 & 11.73 & 31.97 \\
\hline Pisidium & $\begin{array}{l}\text { P. casertanum } \\
P . \text { subtruncatum }\end{array}$ & *Planorboidea & 2.44 & 23.66 & 54.02 \\
\hline
\end{tabular}

* within the class Gastropoda, superfamily is given instead of Order as Orders are not defined for these taxa

807

808 
809 Table 4. Results of partial Canonical Correspondence Analysis (pCCA) of invertebrate taxa

810 living on macrophytes in rivers. Taxonomic groups which were present in more than one

811 sample and for which $>0.5 \%$ of variation is explained by Elodea nuttallii are shown. Table

812 details taxa scores when Elodea nuttallii is fitted as the explanatory variable, variance

813 explained by percentage cover of Elodea nuttallii, and the variance explained by the full

814 model.

815

\begin{tabular}{|c|c|c|c|c|c|}
\hline Taxa & Species present & Order & $\begin{array}{c}\text { CCA scores } \\
\text { against Elodea } \\
\text { nuttallii only }\end{array}$ & $\begin{array}{c}\text { Variance explained } \\
\text { by Elodea nuttallii } \\
(\%)\end{array}$ & $\begin{array}{c}\text { Variance } \\
\text { explained by full } \\
\text { model }(\%)\end{array}$ \\
\hline Crangonyx & C. pseudogracilis & Amphipoda & -3.07 & 40.46 & 55.82 \\
\hline Sialis & S. lutaria & Megaloptera & -2.78 & 37.99 & 52.11 \\
\hline Bithynia & B. tentaculata & *Truncatelloidea & -1.88 & 29.44 & 55.33 \\
\hline Pisidium & $\begin{array}{l}\text { P. amnicum } \\
\text { P. casertanum }\end{array}$ & Veneroida & -1.81 & 6.49 & 13.26 \\
\hline Theromyzon & T. tessulatum & Rhynchobdellida & -1.66 & 9.72 & 52.30 \\
\hline Haliplus & H. confinis & Coleoptera & -1.29 & 7.74 & 59.27 \\
\hline Stictotarsus & S. duodecimpustulatus & Coleoptera & -1.18 & 6.94 & 61.61 \\
\hline Coenagrionidae & Spp. & Odonata & -0.89 & 1.12 & 16.89 \\
\hline Asellus & A. aquaticus & Amphipoda & -0.59 & 14.33 & 57.41 \\
\hline Physa & P. fontinalis & *Planorboidea & -0.44 & 3.23 & 57.12 \\
\hline Chironomidae & spp. & Diptera & -0.36 & 1.24 & 13.24 \\
\hline Helobdella & H. stagnalis & Rhynchobdellida & -0.29 & 3.75 & 64.28 \\
\hline Lymnaea & $\begin{array}{l}\text { L. palustris } \\
\text { L. stagnalis } \\
\text { L. peregra } \\
\text { L. trunculata }\end{array}$ & *Lymnaeoidea & -0.26 & 1.32 & 81.69 \\
\hline Cortixinae & Spp. & Hemiptera & 0.67 & 1.89 & 32.35 \\
\hline Valvata & $V$. piscinalis & *Valvatoidea & 0.85 & 1.91 & 28.78 \\
\hline Gyraulus & G. albus & *Planorboidea & 0.87 & 5.58 & 72.10 \\
\hline Gammarus & G. pulex & Amphipoda & 0.97 & 5.26 & 25.61 \\
\hline Planorbis & P. carinatus & *Planorboidea & 1.19 & 22.78 & 60.58 \\
\hline Planorbarius & P. corneus & *Planorboidea & 1.28 & 20.42 & 75.93 \\
\hline Notonecta & Spp. & Hemiptera & 1.28 & 9.16 & 17.87 \\
\hline Limnephilidae & Spp. & Trichoptera & 1.28 & 8.45 & 64.97 \\
\hline Glossiphonia & $\begin{array}{l}\text { G. complanata } \\
\text { G. heteroclite }\end{array}$ & Rhynchobdellida & 2.28 & 20.12 & 40.63 \\
\hline Hippeutis & H. complanatus & *Planorboidea & 2.69 & 14.39 & 38.29 \\
\hline
\end{tabular}

* within the class Gastropoda, superfamily is given instead of Order as Order is not defined for these taxa

816 


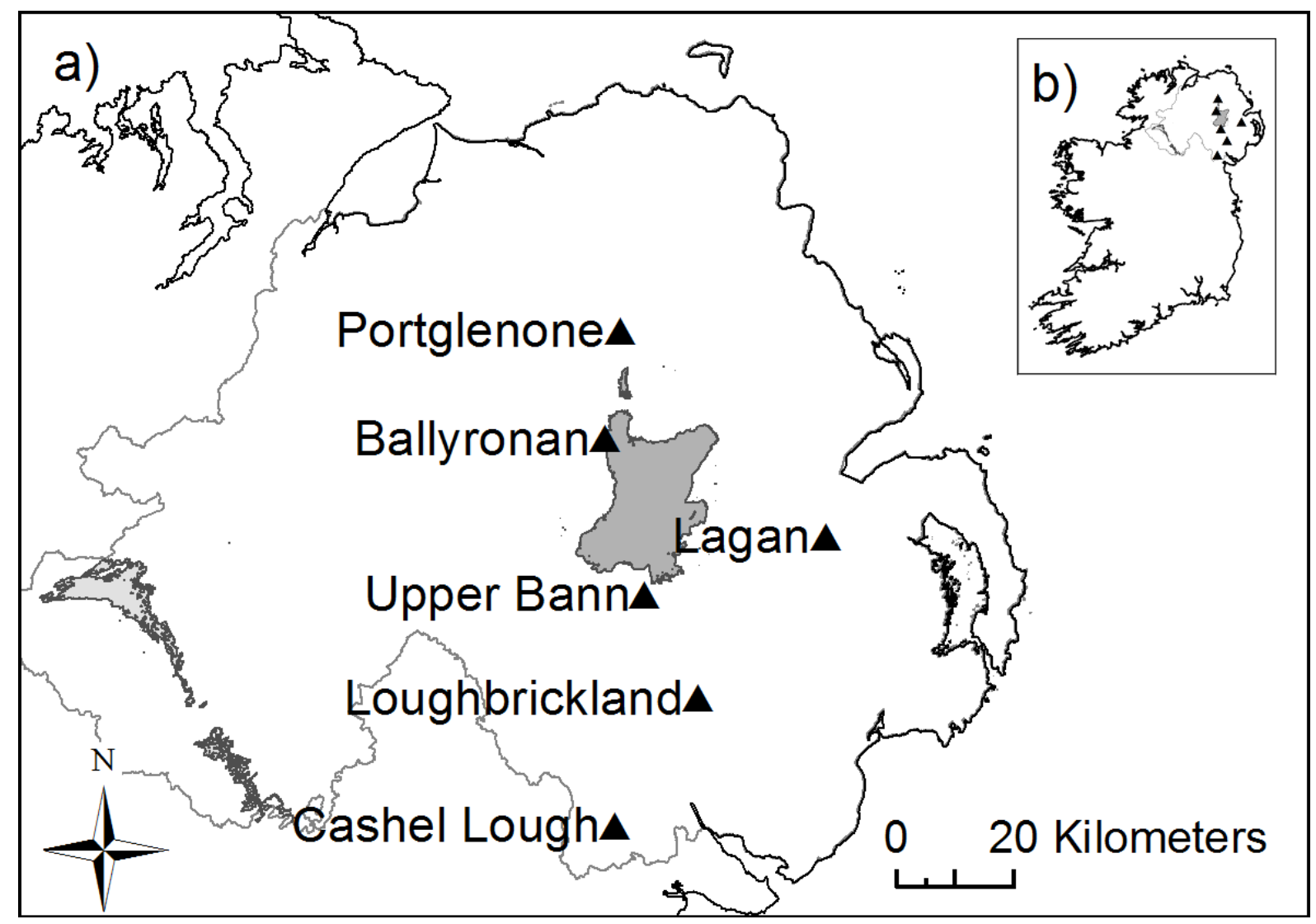

819 Fig. 1 a) Field sites for study of impacts of Elodea nuttallii on dissolved oxygen, chorophyll

$820 a, \mathrm{pH}$, algae and invertebrates. Samples were paired within sites such that samples were taken

821 from a stand of E. nuttallii and a stand of native plants within each site, b) inset map of 822 Ireland showing field site locations.

823 


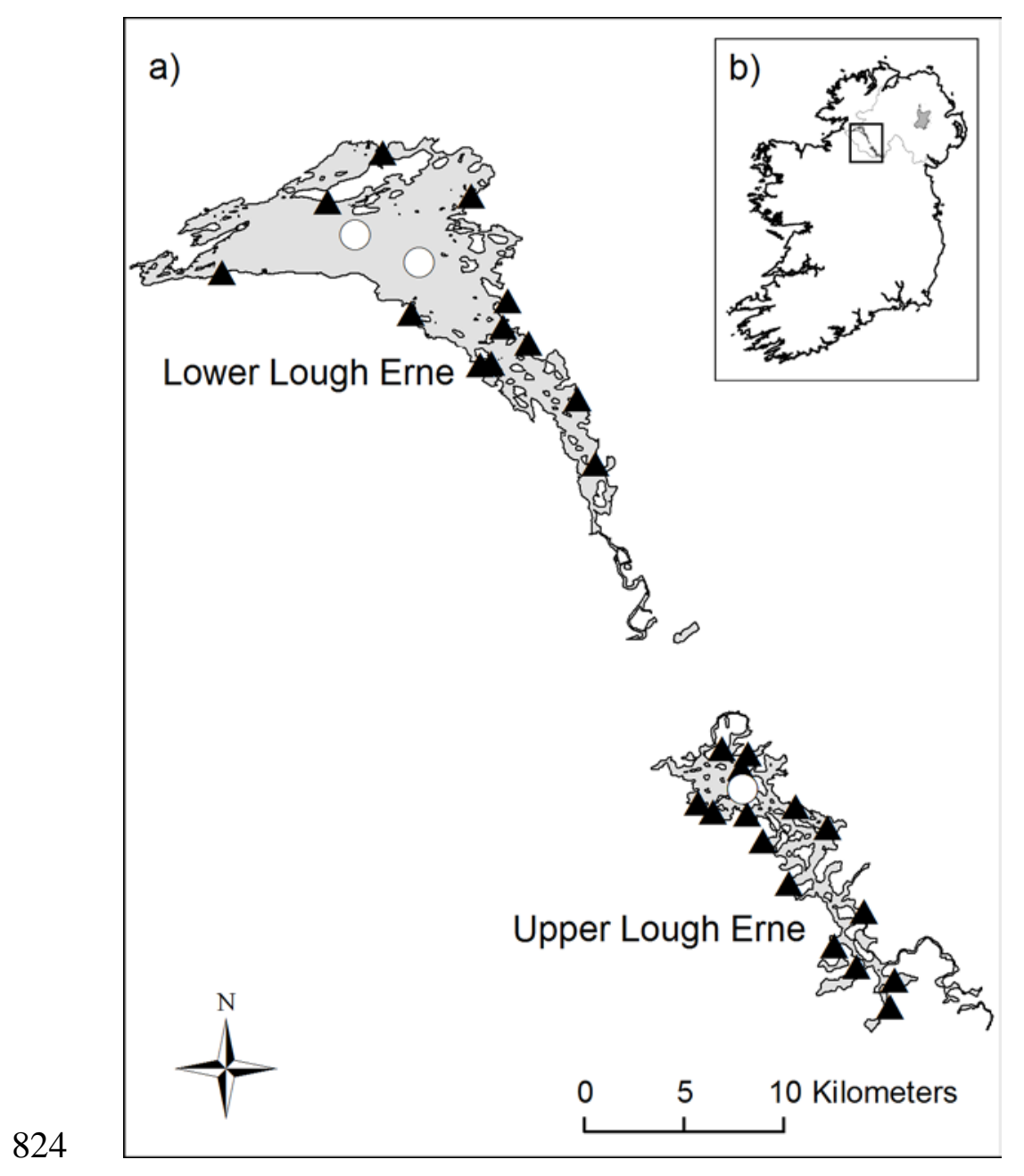

825

826 Fig. 2 a) Study sites for macrophytes in Lough Erne. Black triangles show the locations of 827 survey transects. White circles show locations where water chemistry parameters were 828 measured, b) inset map of Ireland showing location of Lough Erne. 


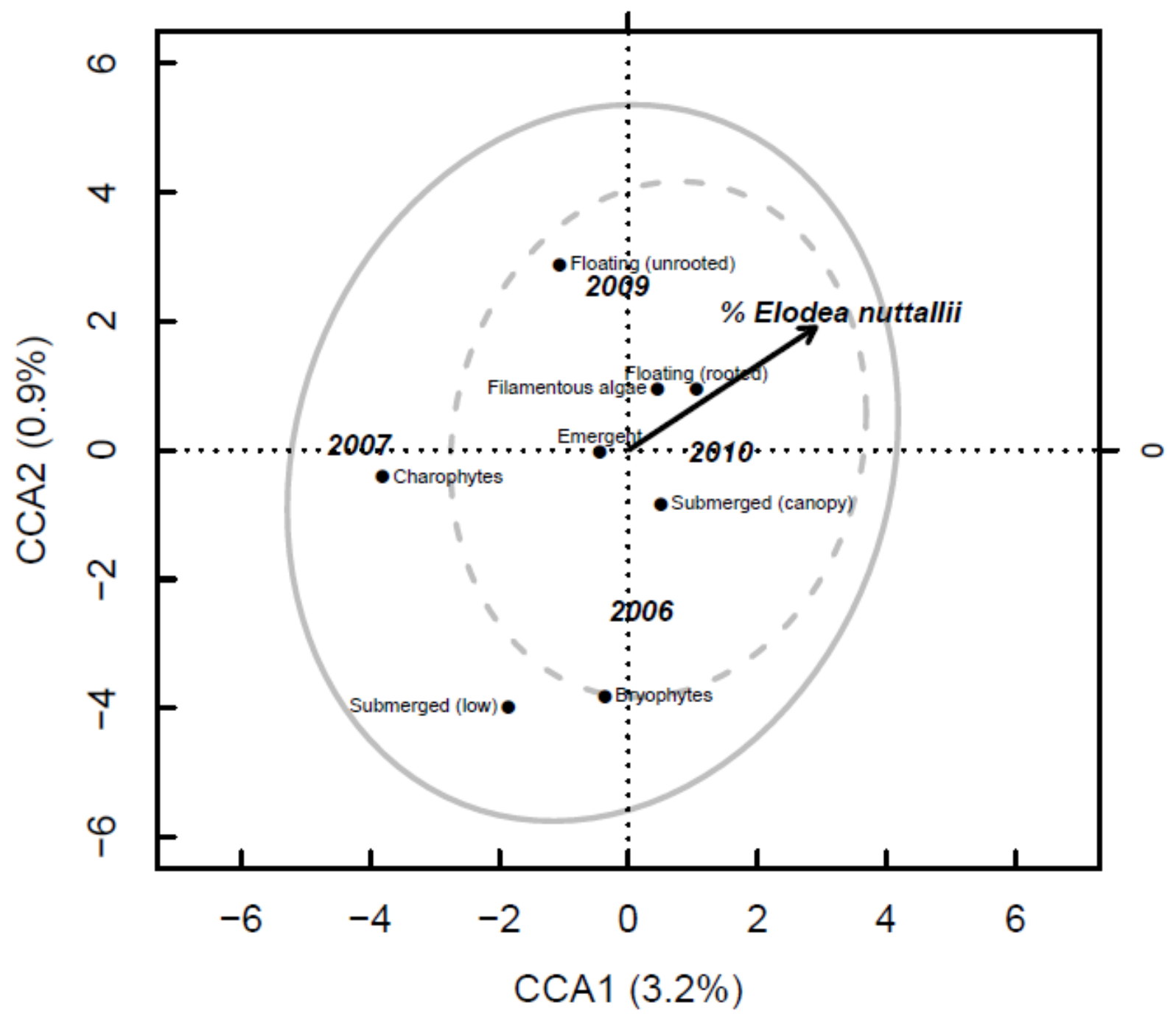

829

830 Fig. 3 Plot of partial Canonical Correspondence Analysis showing relationships between

831 Elodea nuttallii and plant functional groups, when year is also fitted an explanatory factor

832 and quadrat ID is accounted for as a random factor. Species scores are unscaled. Axis labels

833 show \% of total variation in macrophyte communities explained by each CCA axis. Grey

834 ellipse shows 95\% confidence interval around sites where Elodea nuttallii is present, dashed

835 grey ellipse shows 95\% confidence interval around sites where Elodea nuttallii is not present. 


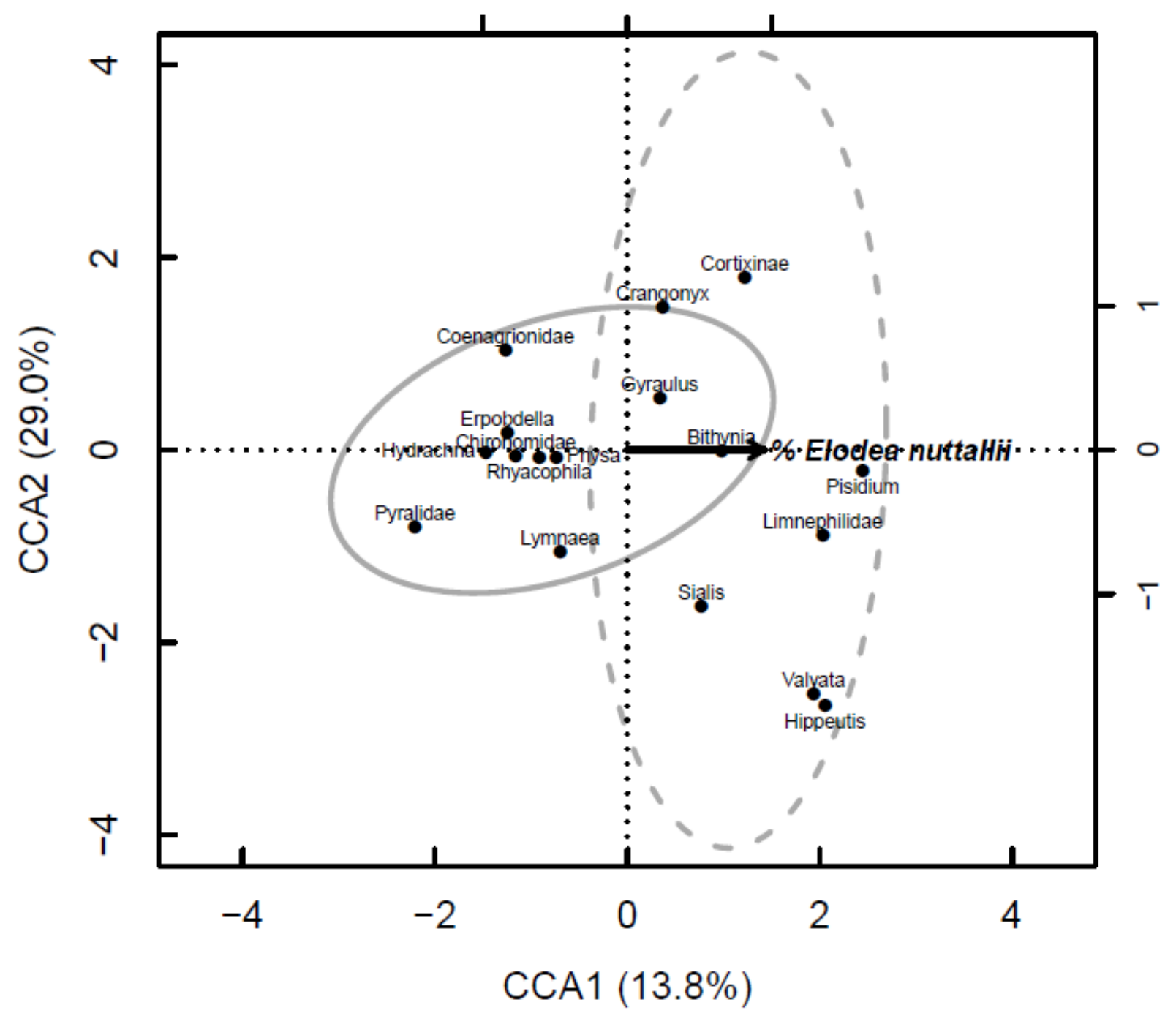

836

Fig. 4 Plot of partial Canonical Correspondence Analysis showing relationships between

838 Elodea nuttallii and invertebrate taxa in lakes, when site is accounted for as a random factor.

839 Species scores are unscaled. Taxonomic groups which were present in more than one sample

840 and for which $>0.5 \%$ of variation is explained by Elodea nuttallii are shown. Axis labels

841 show \% of total variation in macrophyte communities explained by each CCA axis. Grey

842 ellipse shows 95\% confidence interval around sites where Elodea nuttallii is present, dashed

843 grey ellipse shows 95\% confidence interval around sites where Elodea nuttallii is not present.

844 


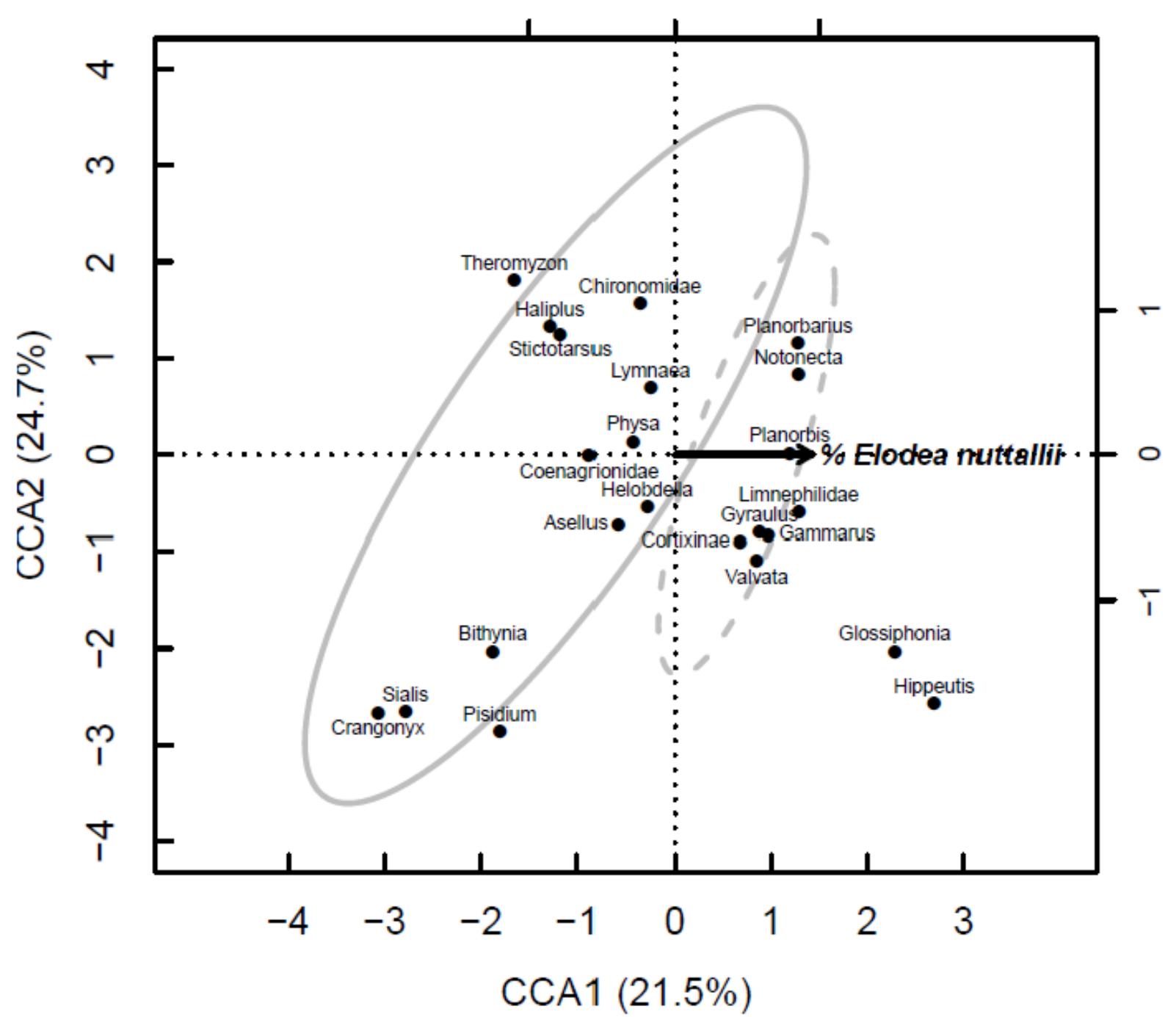

Fig. 5 Plot of partial Canonical Correspondence Analysis showing relationships between

847 Elodea nuttallii and invertebrate taxa in rivers, when site is accounted for as a random factor.

848 Species scores are unscaled. Taxonomic groups which were present in more than one sample

849 and for which $>0.5 \%$ of variation is explained by Elodea nuttallii are shown. Axis labels

850 show \% of total variation in macrophyte communities explained by each CCA axis. Grey

851 ellipse shows 95\% confidence interval around sites where Elodea nuttallii is present, dashed

852 grey ellipse shows 95\% confidence interval around sites where Elodea nuttallii is not present. 
855

856 Table S1 Algal functional groups used

857 Table S2 Invertebrate biomass regression models

858 Table S3 Invertebrate feeding guilds

859 Table S4 Macrophyte structural groups

860 Table S5 Model details of macrophyte GLMMs

861 Table S6 Model details of macrophyte pCCAs

862 Table S7 Model details of GLMMs of dissolved oxygen, chorophyll $a$, $\mathrm{pH}$ and plant 863 biomass.

864 Table S8 Model details of algae GLMMs

865 Table S9 Model details of algae pCCAs

866 Table S10 Model details of invertebrate GLMMs

867 Table S11 Model details of invertebrate pCCAs

868 Table S12 Model details for multivariate analyses of homogeneity.

869 


\section{Supplementary material}

Table 1 Algal functional groups. Table shows which taxonomic groups were placed in each functional group for analysis.

\begin{tabular}{|c|c|c|}
\hline Group & Key morphological features & Taxonomic group \\
\hline 1 & $\begin{array}{l}\text { Small organisms with high } \\
\text { surface/volume ratio }\end{array}$ & Lyngbya, Oscillatoria, picoplankton, Stichococcus \\
\hline 2 & $\begin{array}{l}\text { Small, flagellated, with siliceous } \\
\text { exoskeletal features }\end{array}$ & Chromulina, Chrysophyta, Synura \\
\hline 3 & Large filaments with aerotopes & Anabaena spiroides, Chroococcales, Hapalosiphon, Nostoc \\
\hline 4 & $\begin{array}{l}\text { Medium size organisms, lacking } \\
\text { specialised traits }\end{array}$ & $\begin{array}{l}\text { Ankyra, Aphanochaete magna, Bumilleriopsis, } \\
\text { Characiochloris, Characiopsis, Characium, Closteriopsis } \\
\text { acicularis, Closterium, Cosmarium, Microthamnion } \\
\text { kuetzingianum, Monoraphidium, Mougeotia, } \\
\text { Netrium, Oedogonium, Ophiocytium, Pediastrum duplex, } \\
\text { Pediastrum tetras, Scenedesmus, Tetraedron, Tetrastrum } \\
\text { staurogeniaeforme, Treubaria }\end{array}$ \\
\hline 5 & Medium to large flagellates & $\begin{array}{l}\text { Chlamydomonas, Chroomonas, Cryptomonas, Dinophyceae } \\
\text { Euglena, Gymnodinium, Haematococcus, Katodinium, } \\
\text { Pandorina morum, Phacus, Trachelomonas }\end{array}$ \\
\hline 6 & $\begin{array}{l}\text { Non-flagellates with siliceous } \\
\text { exoskeletons }\end{array}$ & $\begin{array}{l}\text { Achnanthes, Achnanthidium, Amphora, Aulacoseira } \\
\text { Cocconeis, Cyclotella, Cymbella, Denticula, Diadesmis, } \\
\text { Encyonema, Epithemia, Eunotia, Fragilaria, Frustulia, } \\
\text { Gomphonema, Gyrosigma, Melosira varians, Meridion, } \\
\text { Navicula, Nitzschia, Pinnularia, Pseudostaurosira, } \\
\text { Rhoicosphenia curvata, Staurosirella, Stephanodiscus, } \\
\text { Surirella }\end{array}$ \\
\hline 7 & Large mucilaginous colonies & $\begin{array}{l}\text { Chamaesiphon, Chlorococcales, Gomphosphaeria, } \\
\text { Hydrococcus, Kirchneriella obesa, Lagerheimia genevensis, } \\
\text { Merismopedia, Microcystis, Oscillatoria, Phormidium, } \\
\text { Protoderma, Quadrigula, Radiococcus, Rhabdoderma }\end{array}$ \\
\hline 8 & Uncategorised genera & Unidentifiable genera \\
\hline
\end{tabular}


Table S2 Best fitting invertebrate biomass regression models and formulae. Optimal regressions based on width/length ( $\mathrm{mm}$ ) and biomass (mg) of invertebrate taxa.

\begin{tabular}{lcccccc}
\hline $\begin{array}{l}\text { Invertebrate } \\
\text { Taxa }\end{array}$ & $\boldsymbol{n}$ & $\boldsymbol{p}$ & $\begin{array}{c}\text { Adj } \\
\mathbf{R}^{2}\end{array}$ & $\begin{array}{c}\text { Intercept } \\
\text { (SE) }\end{array}$ & $\begin{array}{c}\text { Slope } \\
\text { (SE) }\end{array}$ & $\begin{array}{c}\text { X variable + } \\
\text { tranformation }\end{array}$ \\
\hline Asellidae & 162 & $<0.001$ & 0.70 & $-5.07(0.25)$ & $2.67(0.14)$ & Length (Ln) \\
Bithyniidae & 57 & $<0.001$ & 0.80 & $-2.59(0.29)$ & $2.01(0.13)$ & Length (Ln) \\
Chironomus & 29 & $<0.001$ & 0.62 & $-4.18(0.68)$ & $1.67(0.24)$ & Length (Ln) \\
Erpobdellidae & 15 & $<0.001$ & 0.92 & $-9.17(0.72)$ & $3.22(0.25)$ & Length (Ln) \\
Glossiphonidae & 24 & 0.0402 & 0.13 & $-1.82(0.64)$ & $0.63(0.29)$ & Length (Ln) \\
Hydrobiidae & 156 & $<0.001$ & 0.40 & $-3.36(0.22)$ & $1.75(0.17)$ & Length (Ln) \\
Lymnaeidae & 81 & $<0.001$ & 0.72 & $-3.76(0.35)$ & $2.59(0.18)$ & Length (Ln) \\
Physidae & 6 & $<0.001$ & 0.85 & $-2.77(0.64)$ & $2.00(0.37)$ & Length (Ln) \\
Planorbidae & 24 & $<0.001$ & 0.72 & $-1.23(0.18)$ & $2.06(0.27)$ & Width (Log 10$)$ \\
Sphaeriidae & 18 & $<0.001$ & 0.74 & $-4.55(0.56)$ & $2.54(0.35)$ & Width (Ln) \\
Valvatidae & 52 & $<0.001$ & 0.69 & $-3.41(0.27)$ & $2.75(0.25)$ & Width (Ln) \\
\hline
\end{tabular}


Table S3 Invertebrate feeding guilds. Table shows which taxonomic groups were placed in each feeding guild for analysis.

\begin{tabular}{|c|c|c|c|c|c|}
\hline Collector Filterer & Collector Gatherer & Herbivore Piercer & Predator & Scraper Grazer & Shredder \\
\hline Chydoridae & Baetidae & Corixinae & Argyroneta & Asellus & Chrysomelidae \\
\hline Culicidae & Beraea & Curculionidae & Batracobdella & Bithynia & Elminthidae \\
\hline Cyclopoida & Caenis & Donacia & Chaoboridae & Brychius & Gammarus \\
\hline Daphniidae & Dicrotendipes & Macroplea & Coenagrionidae & Crangonyx & Helophorus \\
\hline Pisidium & Endochironomus & & Dytiscidae & Gyraulus & Pyralidae \\
\hline Polycentropodidae & Chironomidae & & Erpobdella & Haliplidae & Glyptotendipes \\
\hline \multirow[t]{12}{*}{ Microtendipes } & Chironomus & & Gerris & Haliplus & Polypedilum \\
\hline & Limnephilidae & & Glossiphonia & Hippeutis & \\
\hline & Oligochaeta & & Helobdella & Lymnaea & \\
\hline & & & Hydrachna & Physa & \\
\hline & & & Limnesia & Planorbarius & \\
\hline & & & Nepidae & Planorbis & \\
\hline & & & Notonecta & Potamopyrgus & \\
\hline & & & Rhyacophila & Valvata & \\
\hline & & & Sialis & & \\
\hline & & & Stictotarsus & & \\
\hline & & & Theromyzon & & \\
\hline & & & Velia & & \\
\hline
\end{tabular}


Table S4 Macrophyte structural groups. Table shows which taxonomic groups were placed in each structural group for analysis.

\begin{tabular}{ll}
\hline Structural group & Taxonomic group \\
\hline Emergent & Alisma lanceolatum, Alisma plantago-aquatica, Apium inundatum, Baldellia ranunculoides, Butomus umbellatus, Caltha palustris, \\
& Carex rostrata, Carex vesicaria, Cicuta virosa, Eleocharis palustre, Epilobium hirsutum, Equisetum fluviatile, Equisetum palustre, \\
& Filipendula ulmaria, Glyceria fluitans, Iris pseudacorus, Juncus bulbosus, Lythrum spp., Mentha aquatica, Menyanthes trifoliata, \\
& Myosotis scorpioides, Phalaris arundinacea, Phragmites australis, Persicaria amphibia, Potentilla palustris, Ranunculus flammula, \\
& Schoenoplectus spp., Solanum dulcamara, Sparganium erectum, Stachys palustris, Typha latifolia \\
Free-floating & Hydrocharis morsus-ranae, Lemna gibba, Lemna minor, Lemna minuta, Lemna polyrhiza, Lemna trisulca, Stratiotes aloides \\
Floating rooted & Nuphar lutea, Nymphaea alba, Potamogeton natans, Sagittaria sagittifolia \\
Submersed, canopy & Callitriche spp., Callitriche hamulata, Ceratophyllum demersum, Elodea canadensis, Elodea nuttallii, Myriophyllum alternifolium, \\
forming & Myriophyllum spicatum, Potamogeton alpina, Potamogeton crispus, Potamogeton filiformis, Potamogeton friesii, Potamogeton \\
& gramineus Potamogeton lucens, Potamogeton obtusifolius, Potamogeton pectinatus, Potamogeton perfoliatus, Potamogeton \\
praelongus, Potamogeton pusillus, Potamogeton trichoides, Potamogeton gramineus x lucens, Ranunculus penicillatus, Ranunculus \\
Submersed, low & circinatus, Sparganium emersum, Zannichella palustre \\
growing & Eleocharis acicularis, Isoetes spp., Littorella uniflora \\
Bryophytes & Fontinalis antipyretica, Fontinalis squamosa, Scapania spp. \\
Filamentous algae & Chlorophyta \\
Charophytes & Charophyceae
\end{tabular}


Table S5. Univariate models of macrophyte cover and species richness, where quadrat nested within lake was fitted as a random factor. "na” indicates variables not included in the final model.

\begin{tabular}{|c|c|c|c|}
\hline Model/explanatory variables & $\bar{\beta} \pm$ s.e. & Wald $\chi^{2}$ & $\bar{p}$ \\
\hline \multicolumn{4}{|c|}{ a) \% macrophytes cover $\left(\chi_{\mathrm{df}=717}^{2}=180.88, p<0.001\right)$} \\
\hline$\%$ Elodea nuttallii & $0.013 \pm 0.003$ & 20.24 & $<0.001$ \\
\hline \% Elodea canadensis & $0.029 \pm 0.012$ & 5.53 & 0.019 \\
\hline Depth & $-0.470 \pm 0.083$ & 31.90 & $<0.001$ \\
\hline Year & Factorial & 8.47 & 0.037 \\
\hline Nutrient concentration & $-3.690 \pm 2.109$ & 3.06 & 0.080 \\
\hline$\%$ E. nuttallii * \% E. canadensis & na & & \\
\hline \multicolumn{4}{|c|}{ b) $\%$ native macrophytes cover $\left(\chi_{\mathrm{df}=719}^{2}=101.74, p<0.001\right)$} \\
\hline \% Elodea nuttallii & na & na & na \\
\hline \% Elodea canadensis & na & na & na \\
\hline Depth & $-0.494 \pm 0.087$ & 32.42 & $<0.001$ \\
\hline Year & Factorial & 9.51 & $<0.001$ \\
\hline Nutrient concentration & $-4.082 \pm 2.214$ & 3.40 & 0.065 \\
\hline$\%$ E. nuttallii * \% E. canadensis & na & & \\
\hline \multicolumn{4}{|c|}{ c) $\%$ native macrophyte richness $\left(\chi_{\mathrm{df}=717}^{2}=, p<0.001\right)$} \\
\hline \% Elodea nuttallii & $0.002 \pm 0.001$ & 3.85 & 0.050 \\
\hline \% Elodea canadensis & $0.013 \pm 0.004$ & 11.58 & \\
\hline Depth & $-0.397 \pm 0.043$ & 88.77 & \\
\hline Year & Factorial & 26.86 & \\
\hline Nutrient concentration & $3.407 \pm 1.176$ & 8.39 & 0.004 \\
\hline$\%$ E. nuttallii * \% E. canadensis & na & & \\
\hline
\end{tabular}

Table S6. Results of pCCA models of cover of macrophyte genera and cover of macrophyte structural groups, where quadrat is accounted for as a conditional factor. "na“ indicates variables which were not included in the final model.

\begin{tabular}{|c|c|c|}
\hline Model/explanatory variables & Variance explained (\%) & $p$ \\
\hline \multicolumn{3}{|c|}{$\begin{array}{l}\text { a) \% cover of macrophyte genera } \\
(\mathrm{df}=697 \text {, Conditional variance }(\text { Site })=53.9 \text {, Constrained variance }=3.9, p=0.010)\end{array}$} \\
\hline$\%$ Elodea nuttallii & 0.5 & 0.005 \\
\hline$\%$ Elodea canadensis & na & na \\
\hline Depth & 0.5 & 0.005 \\
\hline Year & 2.0 & 0.005 \\
\hline Nutrient concentration & na & na \\
\hline$\%$ E. nuttallii * \% E. canadensis & na & na \\
\hline \multicolumn{3}{|c|}{$\begin{array}{l}\text { b) \% cover of structural groups } \\
(\mathrm{df}=361 \text {, Conditional variance }(\text { Site })=69.0 \text {, Constrained variance }=4.6, p=0.005)\end{array}$} \\
\hline \% Elodea nuttallii & 0.6 & 0.005 \\
\hline \% Elodea canadensis & na & na \\
\hline Depth & na & na \\
\hline Year & 2.7 & 0.005 \\
\hline Nutrient concentration & na & na \\
\hline$\%$ E. nuttallii $* \%$ E. canadensis & na & na \\
\hline
\end{tabular}


Table S7. Results of univariate models of dissolved oxygen, chlorophyll $a$, pH, and plant biomass where site is fitted as a random factor. "na“ indicates variables not included in the final model.

\begin{tabular}{|c|c|c|c|}
\hline Model/explanatory variables & $\beta \pm$ s.e. & Wald $\chi^{2}$ & $p$ \\
\hline \multicolumn{4}{|c|}{ a) dissolved oxygen saturation $\left(\chi_{\mathrm{df}=31}^{2}=6.25, p=0.043\right)$} \\
\hline Elodea nuttallii & Factorial & 3.21 & 0.073 \\
\hline Month & na & na & na \\
\hline Nutrient concentration & na & na & na \\
\hline Nutrient concentration $*$ E. nuttalii & na & na & na \\
\hline River/Lake & Factorial & 4.23 & 0.040 \\
\hline River/Lake * E. nuttallii & na & na & na \\
\hline \multicolumn{4}{|l|}{ b) chlorophyll a $\left(\chi_{\mathrm{df}=34}^{2}=1.61, p=0.204\right)$} \\
\hline Elodea nuttallii & na & na & na \\
\hline Month & na & na & na \\
\hline Nutrient concentration & na & na & na \\
\hline Nutrient concentration ${ }^{*} E$. nuttalii & na & na & na \\
\hline River/Lake & na & na & na \\
\hline River/Lake ${ }^{*}$ E. nuttallii & na & na & na \\
\hline \multicolumn{4}{|l|}{ c) $\mathbf{p H}\left(\chi_{\mathrm{df}=33}^{2}=40.45, p<0.001\right)$} \\
\hline Elodea nuttallii & na & na & na \\
\hline Month & Factorial & 125.69 & $<0.001$ \\
\hline Nutrient concentration & na & na & na \\
\hline Nutrient concentration $*$ E. nuttalii & na & na & na \\
\hline River/Lake & na & na & na \\
\hline River/Lake $*$ E. nuttallii & na & na & $\mathrm{Na}$ \\
\hline \multicolumn{4}{|c|}{ d) plant biomass $\left(\chi_{\mathrm{df}=23}^{2}=1.99, p=0.158\right)$} \\
\hline Elodea nuttallii & na & na & na \\
\hline Month & na & na & na \\
\hline Nutrient concentration & na & na & na \\
\hline Nutrient concentration ${ }^{*} E$. nuttalii & na & na & na \\
\hline River/Lake & na & na & na \\
\hline River/Lake ${ }^{*}$ E. nuttallii & na & na & na \\
\hline
\end{tabular}


Table S8. Results of univariate models of algal biovolume and richness of algal taxa, where site is fitted as a random factor. "na“ indicates variables which were not included in the final model.

\begin{tabular}{|c|c|c|c|}
\hline Model/explanatory variables & $\beta \pm$ s.e. & Wald $\chi^{2}$ & $p$ \\
\hline \multicolumn{4}{|c|}{ a) algal biovolume $\left(\chi^{2} \mathrm{df}=29=7.32, p=0.026\right)$} \\
\hline Elodea nuttallii & na & na & na \\
\hline Month & Factorial & 8.40 & 0.015 \\
\hline Nutrient concentration & na & na & na \\
\hline Nutrient concentration $*$ E. nuttalii & na & na & na \\
\hline River/Lake & na & na & na \\
\hline River/Lake * E. nuttallii & na & na & na \\
\hline \multicolumn{4}{|c|}{ b) richness of algal taxa $\left(\chi_{\mathrm{df}=27}^{2}=177.68, p<0.001\right)$} \\
\hline Elodea nuttallii & na & 3.67 & 0.055 \\
\hline Month & na & 20.19 & $<0.001$ \\
\hline Nutrient concentration & na & na & na \\
\hline Nutrient concentration * E. nuttalii & na & na & na \\
\hline River/Lake & na & na & na \\
\hline River/Lake ${ }^{*}$ E. nuttallii & na & na & na \\
\hline
\end{tabular}

Table S9. Results of pCCA models of algal taxa and algal functional groups, where site is accounted for as a conditional factor. "na“" indicates variables which were not included in the final model.

\begin{tabular}{lcc}
\hline Model/explanatory variables & Variance explained (\%) & $\boldsymbol{p}$ \\
\hline & & \\
a) biovolume of algal taxa & & \\
(df $=23$, Conditional variance(Site) & 34.5, Constrained variance $=15.5, p=0.015$ ) \\
Elodea nuttallii & na & na \\
Month & 7.1 & 0.041 \\
Nutrient concentration & 5.3 & 0.030 \\
Nutrient concentration*E.nuttallii & na & na \\
River/Lake & na & na \\
River/Lake * E. nuttallii & na & na \\
& & \\
b) biovolume of functional groups & & na \\
(df = 25, Conditional variance(Site) & 19.1, Constrained variance = $0, p=0.340$ ) \\
Elodea nuttallii & na & na \\
Month & na & na \\
Nutrient concentration & na & na \\
Nutrient concentration*E.nuttallii & na & na \\
River/Lake & na & na \\
River/Lake * E. nuttallii & na &
\end{tabular}


Table S10. Results of univariate models of invertebrate biomass and richness, where site is fitted as a random factor. "na“ indicates variables which were not included in the final model.

\begin{tabular}{|c|c|c|c|}
\hline Model/explanatory variables & $\beta \pm$ s.e. & Wald $\chi^{2}$ & $p$ \\
\hline \multicolumn{4}{|c|}{ a) biomass of invertebrates on macrophytes $\left(\chi_{\mathrm{df}=18}^{2}=20.87, p<0.001\right)$} \\
\hline Elodea nuttallii & na & na & na \\
\hline Month & Factorial & 12.05 & $<0.001$ \\
\hline Nutrient concentration & $0.561 \pm 0.200$ & 7.85 & $<0.001$ \\
\hline Nutrient concentration $*$ E. nuttalii & na & na & na \\
\hline Plant density & $0.495 \pm 0.120$ & 17.01 & $<0.001$ \\
\hline River/Lake & na & na & na \\
\hline River/Lake * E. nuttallii & na & na & na \\
\hline \multicolumn{4}{|c|}{ b) richness of invertebrates on macrophytes $\left(\chi_{\mathrm{df}=21}^{2}=13.33, p=0.002\right)$} \\
\hline Elodea nuttallii & na & na & na \\
\hline Month & Factorial & 6.30 & 0.012 \\
\hline Nutrient concentration & na & na & $\mathrm{Na}$ \\
\hline Nutrient concentration $*$ E. nuttalii & na & na & $\mathrm{Na}$ \\
\hline Plant density & $0.125 \pm 0.075$ & 2.76 & 0.096 \\
\hline River/Lake & na & na & na \\
\hline River/Lake * E. nuttallii & na & na & na \\
\hline \multicolumn{4}{|c|}{ c) biomass of invertebrates in sediment $\left(\chi^{2} \mathrm{df}=20=8.93, p<0.001\right)$} \\
\hline Elodea nuttallii & na & na & na \\
\hline Month & na & na & na \\
\hline Nutrient concentration & $0.792 \pm 0.341$ & 9.54 & 0.002 \\
\hline Nutrient concentration $*$ E. nuttalii & na & na & na \\
\hline Plant density & na & na & na \\
\hline River/Lake & na & na & na \\
\hline River/Lake $*$ E. nuttallii & na & na & na \\
\hline \multicolumn{4}{|c|}{ d) richness of invertebrates in sediment $\left(\chi^{2} \mathrm{df}=20=1.99, p=0.158\right)$} \\
\hline Elodea nuttallii & na & na & na \\
\hline Month & na & na & na \\
\hline Nutrient concentration & na & na & na \\
\hline Nutrient concentration $* E$. nuttalii & na & na & na \\
\hline Plant density & na & na & na \\
\hline River/Lake & na & na & na \\
\hline River/Lake $*$ E. nuttallii & na & na & na \\
\hline
\end{tabular}


Table S11. Results of pCCA models of invertebrate taxa and feeding guilds, where site is accounted for as a conditional factor. "na" indicates variables which were not included in the final model.

\begin{tabular}{lll}
\hline Model/explanatory variables & Variance explained (\%) & $p$ \\
\hline
\end{tabular}

a) biomass of invertebrate taxa on macrophytes

$(\mathrm{df}=15$, Conditional variance $($ Site $)=39.9$, Constrained variance $=0, p=0.017)$

Elodea nuttallii

na

Month

Nutrient concentration

na na

na

Nutrient concentration*E.nuttallii

na na

Plant density

na

River/Lake

na

River/Lake * E. nuttallii

na

b) biomass of invertebrate feeding guilds on macrophytes

$(\mathrm{df}=17$, Conditional variance $($ Site $)=45.2$, Constrained variance $=10.5, p=0.005)$

Elodea nuttallii na na

Month na na

Nutrient concentration na na

Nutrient concentration*E.nuttallii na na

Plant density na na

River/Lake na na

River/Lake * E. nuttallii $\quad 10.45$

c) biomass of invertebrate taxa in sediment

$(\mathrm{df}=17$, Conditional variance $($ Site $)=42.4$, Constrained variance $=0, p=0.005)$

Elodea nuttallii

па

Month

Nutrient concentration

na

na na

Nutrient concentration*E.nuttallii

Plant density

na

River/Lake

na na

River/Lake * E. nuttallii

c) biomass of invertebrate taxa in sediment

$(\mathrm{df}=17$, Conditional variance $($ Site $)=42.4$, Constrained variance $=0, p=0.005)$

Elodea nuttallii

Month

na na

Nutrient concentration

Nutrient concentration*E.nuttallii

na na

Plant density

na

River/Lake

na

River/Lake * E. nuttallii

na na

na na


Table S12. Results of analyses of multivariate homogeneity of group dispersion for macrophyte, algae and invertebrate taxa. Estimates show mean Jaccard dissimilarity between sites with E. nuttallii present and mean Jaccard dissimilarity between sites without E. nuttallii, based on presence and absence of taxa.

\section{Model/explanatory variables}

mean \pm se

a) macrophyte taxa $\left(F_{\mathrm{df}=726}=24.34, p<0.001\right)$

Elodea nuttallii present

$0.43 \pm<0.01$

Elodea nuttallii absent

$0.49 \pm<0.01$

b) algal $\operatorname{taxa}\left(F_{\mathrm{df}=24}=0.42, p=0.521\right)$

Elodea nuttallii present

$0.49 \pm<0.01$

Elodea nuttallii absent

$0.48 \pm 0.02$

c) invertebrate taxa on macrophytes $\left(F_{\mathrm{df}=22}=0.92, p=0.179\right)$

Elodea nuttallii present

$0.55 \pm 0.03$

Elodea nuttallii absent

$0.60 \pm 0.03$

d) invertebrate taxa in sediment $\left(F_{\mathrm{df}=22}=0.92, p=0.179\right)$

Elodea nuttallii present

$0.51 \pm 0.02$

Elodea nuttallii absent

$0.53 \pm 0.03$ 
